Article

\title{
Multitemporal Analysis as a Non-Invasive Technology Indicates a Rapid Change in Land Use in the Amazon: The Case of the ITT Oil Block
}

\author{
Marco Heredia-R ${ }^{1,2, *}$, Jhenny Cayambe ${ }^{3} \mathbb{D}$, Clint Schorsch $^{4,5}$, Theofilos Toulkeridis ${ }^{5,6} \mathbb{D}^{\mathbb{D}}$, Deniz $^{\text {Barreto }}{ }^{7}$, \\ Paulina Poma ${ }^{8}$ and Gladys Villegas ${ }^{9}$
}

check for updates

Citation: Heredia-R, M.; Cayambe, J.; Schorsch, C.; Toulkeridis, T.; Barreto,

D.; Poma, P.; Villegas, G.

Multitemporal Analysis as a

Non-Invasive Technology Indicates a Rapid Change in Land Use in the Amazon: The Case of the ITT Oil Block. Environments 2021, 8, 139. https://doi.org/10.3390/

environments8120139

Academic Editor: Christine Fürst

Received: 24 November 2021 Accepted: 15 December 2021 Published: 17 December 2021

Publisher's Note: MDPI stays neutral with regard to jurisdictional claims in published maps and institutional affiliations.

Copyright: (c) 2021 by the authors Licensee MDPI, Basel, Switzerland. This article is an open access article distributed under the terms and conditions of the Creative Commons Attribution (CC BY) license (https:// creativecommons.org/licenses/by/ $4.0 /)$.
1 Facultad de Ciencias Agropecuarias, Universidad Técnica Estatal de Quevedo (UTEQ), Quevedo Av. Quito km. $1 \frac{1}{2}$ vía a Santo Domingo de los Tsáchilas, Los Ríos 120550, Ecuador

2 AgSystems, Ceigram, itdUPM, Centro de Innovación en Tecnología para el Desarrollo, Universidad Politécnica de Madrid (UPM), 28040 Madrid, Spain

3 Escuela de Ciencias Agrícolas y Ambientales, Pontificia Universidad Católica del Ecuador Sede Ibarra (PUCESI), Imbabura 100112, Ecuador; jmcayambe@pucesi.edu.ec

4 Departamento de Ciencias de la Vida, Universidad Estatal Amazónica (UEA), Pastaza 160101, Ecuador; schorsch2010@hotmail.com

5 Departamento de Ciencias de la Tierra y Construcción, Universidad de las Fuerzas Armadas ESPE, Sangolquí 171103, Ecuador; ttoulkeridis@espe.edu.ec

6 Carrera de Gestión Ambiental, Universidad de Especialidades Turísticas (UDET), Quito 170408, Ecuador

7 Corporación para el Desarrollo Sostenible, Conservación y Cambio Climático, Tena 150101, Ecuador; d28barreto@gmail.com

8 Department of Chemical Engineering and Environmental Technology, University of Valladolid, 47013 Valladolid, Spain; mariapaulina.poma@alumnos.uva.es

9 Remote Sensing Spatial Analysis Lab (REMOSA), Department of Environment, Ghent University, 9000 Ghent, Belgium; gladysmaria.villegasrugel@ugent.be

* Correspondence: magehere@gmail.com

Abstract: The Amazon Region of Ecuador (ARE) hosts a great variety of biodiversity and ecosystems. These hotspots are internationally recognized for presenting unique fauna and flora found nowhere else in the world. Within the ARE, there is the Yasuní National Park (YNP), a recognized Biosphere Reserve located in the sub-basins of various rivers. The study area is the "ITT Oil Block" (Ishpingo, Tambococha, and Tiputini), situated in the Province of Orellana and superimposed on the YNP. The block has an area of 179,449.53 ha. The main objective of the current study was to analyze the multi-temporality of land-use change in the ITT Oil Block of the ARE. In the methodological process, the PCI Geomatic and ARCGIS programs were used for the processing and classification of satellite images (Landsat 7 and 8). The changes in land use in the ITT Oil Block over the three periods $(2001,2014$, and 2017) indicated that forest cover decreased by $24.23 \%$ in soils, while infrastructure and cultivation increased throughout the time period by $0.27 \%$ and $0.23 \%$, respectively. The most significant land-use change rate in the ITT Oil Block in the period 2001-2017 are the categories of bare soil with $9.01 \%(10,640.82 \mathrm{ha})$ and cultivation with $7.27 \%$ (591.29 ha).

Keywords: Amazon; deforestation; land-use changes; multitemporal; remote sensing

\section{Introduction}

Globally, deforestation is nowadays one of the greatest and rapidly growing environmental problems for the lives of species and human health in predominantly tropical areas [1-4]. Deforestation is mainly a man-made phenomenon worldwide due to the expansion of agricultural farmland, migration of people, and other economic interests such as the installation of oil wells [5-9]. Furthermore, deforestation accelerates erosion, loss of soil cover and biodiversity, spreads vector diseases, drought, or hydric deficits, changes tropical land use, increases surface temperature, global warming, and contributes to climate 
change [10-21]. During the last few decades, scientists have been determining the rate of deforestation in order to inform the public and authorities alike to create awareness regarding such losses that harm human health locally and globally [22-25]. The area with the world's highest deforestation rates is the Amazon rainforest due to the Amazonian countries' erroneous policies and/or interests [26-30].

Ecuador has a deforestation rate of $1.4 \%$ per year, making it the country with the highest deforestation in the entire South American continent [31-35]. The National Department for Planning and Development (Senplades) stated in January 2012 that between 2000 and 2008, Ecuador's annual deforestation rate was $0.63 \%$. This increased to $24 \%$ in 2013 [36]. The Amazon Region of Ecuador (ARE) contains 601,220,100 ha (1.6\%) of forest ecosystems in the Amazon basin however, the deforestation that occurred on Ecuadorian soil between 2000 and 2015 represented 2\% of the total deforestation in the basin. By 2015, Ecuador had lost 12.6\% of its original Amazon forests (212,000 ha of 9,607,300 ha) [37]. In the easternmost area of the ARE, the Ishpingo, Tambococha, and Tiputini Block (ITT) occupies a large part of the Yasuní National Park (YNP) area, as well as the Intangible Tagaeri-Taromenane zone (ZITT), where villages and uncontacted indigenous peoples are settled (Tagaeri-Taromenane).

The oil production of the ITT block in 2017 was developed on the outskirts of the YNP, specifically in the Tiputini area whose processing capacity was 250,000 barrels of fluid per day and in Tambococha where the first reinjection well of the TMBD-02 project was drilled in 2018 [38]. In order to drill wells, it is necessary to clear land to implement oil wells. Therefore, in the ITT Oil Block, people planned to build an access road for transporting machinery that would allow the execution of the project. To that end, 41,1158 ha of land were deforested within the YNP for the 10.7- $\mathrm{km}$ road and 18,1684 ha were destroyed for the five platforms, namely Tambococha A, Tambococha B, Tambocoha E, Tambococha D, and Central de Procesos Tiputini (CPT) [39].

The pollution generated by the oil company causes the loss of biodiversity due to the large amount of solid and liquid waste that results from drilling and exploiting the oil wells [40-43]. The exploitation of the wells requires a large amount of water that depends on the quality of the oil. For instance, if the crude oil is heavy and of poor quality, it will need a greater volume of water [44-46]. In the ITT Oil Block, it needs 10 barrels of water for the extraction of one barrel of oil, that is, oil extraction in the ITT Oil Block will require 100 million cubic meters of water, making reinjection impossible and therefore it is thought that the water's destination would be the Yasuní [47]. Deforestation in Tiputini and Tambococha can affect hunting and agricultural activities for indigenous communities, and the use of habitats hinders the native biodiversity of the area. An evaluation study of the Yasuní indicated that the loss of environmental benefits exceeded the Net Present Value (NPV) that the state can receive. Therefore, Earth Economics estimated them to be 9886 million dollars, a figure that in the order of magnitude of environmental impacts lacks profitability from the exploitation of oil in the Yasuní [48].

Through several cases, scientists have confirmed the effects that oil activities have on humans due to rivers being contaminated by waste generated during the process. Moreover, they have evidenced a high rate of miscarriages (150\%), natal mutations, tropical diseases due to deforestation, cancer among inhabitants due to the bioaccumulation of oil, waste, and chemicals based on the food chain, and even deaths [49]. In the ITT Oil Block and the adjacent Block 31, direct deforestation for platforms and roads was calculated to be $57.3 \mathrm{ha}$, which, if we add the impacts along the border, affected at least 665 ha in both blocks. This is more than double the limit of 300 ha. That was established in the popular consultation of 2018. The construction of the four platforms (Tambococha A, B, D, and E) and the access road between 2017 and 2019 have deforested 28.5 ha of the YNP [50].

The YNP was declared an individual park in 1979, while in 1989, UNESCO recognized it as a Biosphere Reserve for being one of the most biodiverse areas in the world with respect to species, ecosystems, and genetic variability. Indeed, it is a Pleistocene refuge of life. In addition, it houses uncontacted communities in voluntary isolation, hence in 2006 a 
part of the YNP was declared the ZITT [51]. The populations and ecosystems (terrestrial and aquatic) of the ARE are under pressure and constant threat. This occurs due to the formulation and implementation of policies that allow access to and control of Amazonian spaces, resources, and populations with the vision of being a region in which resources are exploited. Furthermore, rural poverty is rife owing to agrarian reforms and colonization from other regions due to lack of land, overpopulation, or environmental deterioration. In addition, oil policies such as agrarian reforms and colonization have favored logging by promoting changes in land use and deterioration of vegetation cover [52].

The YNP is essential for wildlife conservation because there are 2274 species (sp) of trees and shrubs, followed by birds (595 sp), amphibians (150 sp), reptiles (121 sp), and bats $(80 \mathrm{sp})$. There are also more than 4000 species of vascular plants per 1,000,000 ha and it is estimated that there are 100,000 sp of insects per ha. The protection of the YNP's biodiversity is a matter of global concern, since there are overlapping areas in the national park, such as indigenous territories (Waorani, Kichwa, and Shuar), provincial and cantonal governorates, parishes, valuable wood species, and oil blocks that are currently threatening this area [53].

Based on the above, the proposed objective was to evaluate how various anthropic activities, such as deforestation and oil activities affect the change in land use in the ITT Oil Block of the Ecuadorian Amazon. To achieve this task, the multi-temporality of land use change in the ITT Oil Block of the Ecuadorian Amazon was analyzed, classifying the images in the years 2001,2014, and 2017, and identifying the types of land cover in each of the zones by means of quantifying changes in land use. Finally, secondary information was used to investigate the factors associated with changes in land use and possible policy implications for restoration and planning within the study area were determined.

\section{Environmental and Social Context}

Since the 1970s, Ecuador's production model has been based on oil extraction, this has caused harmful situations such as the destruction of the jungle and the disappearance of indigenous communities or isolated peoples [54]. Work on the ITT Oil Block began more than 90 years ago by the company "Leonard Exploration Co.", which received its first concession to explore hydrocarbons in the Amazon region in 1921 in an area of 2,000,000 ha. In 1937, the "Anglo" company received a concession to explore the Amazon region, and in 1938, 10,000,000 ha of the ARE was granted to the "Shell" company, which in 1970, drilled the Tiputini 1 well in the north of the ITT that presented traces of heavy oil from the 11th API (American Petroleum Institute). This occurred in the Tena Basal and M1 formation that was later abandoned on the southern side of the Napo River in a higher structure and with positive results [55]. In 1990, the limits of the YNP were modified to legalize 612,000 ha of lands in favor of the indigenous Waorani people and since then oil concessions in protected areas have been prohibited [56].

In 1992, a text prepared by the Environmental Protection Unit (UPA) stated that after analyzing the country's remaining oil reserves $(2,000,000,000$ barrels) and considering current production (around 300,000 barrels per day), production will progressively decrease if the corrective measures were not carried out before the year 2000. Therefore, Petroecuador through its Petroproducción branch explored the Pañacocha-Tiputini area and detected seven structures (Pañacocha, Sábalo, Paujil, Tiputini, Imuya, Iniwa, and Tambococha), which would contribute estimated reserves of 265,000,000 barrels from the 19th API with a production capacity of 65,000 barrels per day [57].

The "Yasuní-ITT" initiative that was proposed in 2007 offered to keep the oil underground in exchange for $50 \%$ compensation of the income that would have been generated from the exploitation of the ITT field. The scheme provoked national and international debates on the repercussions that Ecuador's economy would experience by not depending on its main exportation. In June of the same year, the proposal was accepted, but the exploitation of the ITT field was maintained as a second alternative in the event that the required funds were not reached. Thus, two proposals were analyzed in this process. The 
first was to leave the oil underground in order to not affect the biodiversity of the area and protect uncontacted groups, and the second was the possibility that Petroamazonas would exploit the ITT using its own resources. However, over the years, there were warnings that the government would exploit the Tiputini and Tambococha fields, which led to the Copenhagen Summit in December 2009. There, the decision was made to give up on negotiations and not sign up to the trust that was to be managed by the United Nations Development Program (UNDP) [58]. In 2012, Petroamazonas began oil exploitation in Block 31, also within the YNP. In 2016, platforms located in the northern limit of the YNP were developed with 50 wells for the extraction of oil from the Tiputini field in the ITT Oil Block [59].

As previously mentioned, there are overlapping indigenous communities in the ITT Oil Block. In Yasuní, the Huaorani people are located in the provinces of Pastaza and Orellana. They occupied more than 2,000,000 ha when they were engaging in huntergatherer activities. Some Huaorani groups have been in voluntary isolation since 1950 but their territories were limited to 758,000 ha. It is estimated that there are currently 2300 Huaorani who occupy the southern part of the Yasuní, delimited by the oil blocks Bloques Amarillo and 14 (West), Block 17 of the Nades, and 31 of Petroamazonas (North), Block Oil ITT of Petroamazonas (Northeast), Peruvian Blocks (East), and China Blocks (South) [60]. Two Waorani groups-Tagaeri and Taromenane-decided not to come into contact with Western people and instead entered the YNP jungle to live in isolation. They live in the ZITT, in the lower middle zone of the Yasuní Reserve with certain movements towards the ITT Oil Block during the chonta (Aiphanes horrida) harvest season [61].

\section{Materials and Methods}

\subsection{Geographic Location}

The study took place in the ITT Oil Block (Ishpingo, Tambococha, and Tiputini), also called Block 43 [62], which is in the Province of Orellana (Aguarico canton), covering an area of $179,449.53$ ha. The Ishpingo and Tambococha fields are within the YNP, while Tiputini is outside of it. The limits of the ITT Oil Block are the Cuyabeno Wildlife Reserve to the north, ZITT to the south, the Peruvian border to the east, and the YNP to the west (Figure 1) [63]. This area comprises lowlands and gently sloping plains covered with sediments of fluvial and lake origin, as well as medium hills, high terraces, and a low river level that in turn belongs to the lower basin of the Napo River and its sub-basins; therefore, the canton remains flooded during bouts of high rainfall.

The ecosystems that exist are the Aguarico-Putumayo-Caquetá lowland evergreen forest, the Amazon (Pantano) flooded forest with palms and alluvial plains, the floodplain forest of alluvial plains with rivers of Andean and Amazonian Cordillera origin, and the Amazon-flooded lake-riparian grassland of alluvial plains $[64,65]$. Their climate is very tropically humid with altitudes of 65 to $600 \mathrm{~m}$ above sea level, an average annual temperatures of between $24^{\circ} \mathrm{C}$ and $27^{\circ} \mathrm{C}$, and high annual rainfall $(3200 \mathrm{~mm}$ to $6315 \mathrm{~mm}$ and high annual relative humidity (80-94\%) [53]. According to the United States Department of Agriculture's (USDA) classification, the soil orders are as follows: Entisol in 60,857.8 ha (5\%), Base Wn in 14,918 ha (1\%), and Inceptisol in 11,042,002 ha (93\%) [66]. The population of the Aguarico canton is 4847 inhabitants (7.1\%) out of a total of 136,396 inhabitants who dwell in the province of Orellana. The households in Aguarico number around 3044 [67]. 


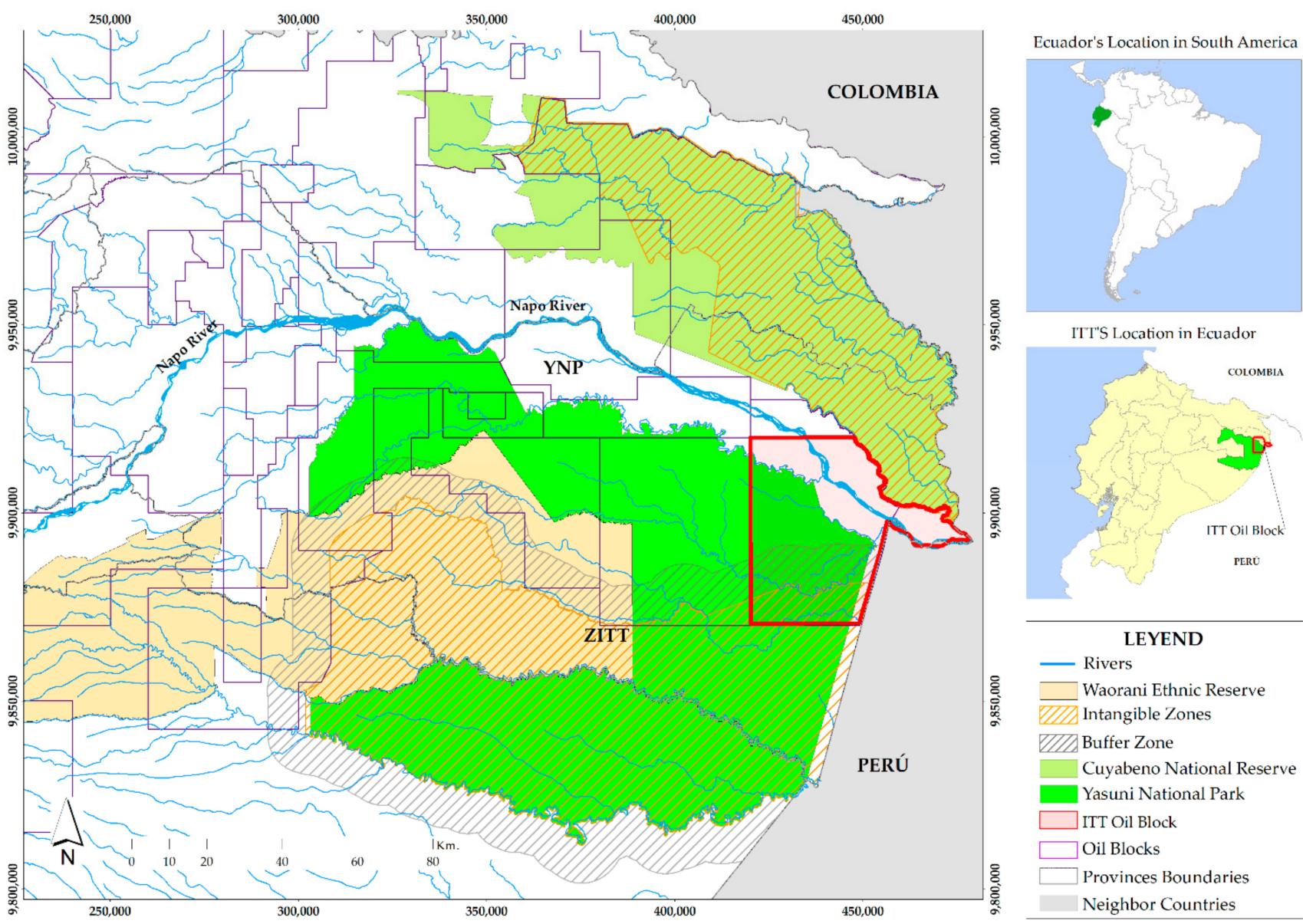

Figure 1. Ishpingo, Tambococha, and Tiputini (ITT) oil block, superimposed between the Yasuní National Park and Cuyabeno Wildlife Reserve, within the Ecuadorian Amazon region.

The ITT Oil Block is superimposed on the landscape of two protected areas, namely the YNP and Cuyabeno Wildlife Reserve, and presents abundant biodiversity with 191 species of mammals, representing $16.23 \%$ of species registered in the eastern tropical floor. Regarding birds, it is home to 25 families belonging to 13 orders, which represents 700 species (6\% of all those in the Amazon) and some 2.59\% of Ecuador's continental species. There are also four recorded species of reptiles (3.08\%), 17 species of amphibians $(11.11 \%)$, and a high number of insect species [68].

\subsection{Method}

Multitemporal analysis is defined as the detection of changes in coverage between two different dates by deducing the evolution of the natural environment or the incidence through anthropic action on it [69]. It was performed by interpreting information from remote sensors by considering satellite images and determining the interpreted units and images of the results [70]. There are several studies in the Ecuadorian Amazon region concerning the implementation, monitoring, and detection of environmental changes with remote sensors, such as in the area of changes in land cover in the fluvial geomorphology of the Tena River [71], and in land use regarding carbon storage in productive systems and primary forests [72]. The change of land cover and use is a dynamic process of expropriation on the ground, related to anthropic activities (livestock, agriculture, etc.) [73]. The change is visible in high parts of mountains, hydrographic basins, and areas adjacent to rivers and streams, which are increasingly larger and occur rapidly, causing loss of forest cover, and a decrease in the quantity and quality of water and soil, thereby affecting communities who 
reside in the basins [74]. It is a conditioner of different types of movements and has an important influence on the hydrological and mechanical properties of the soil [75].

The detection of changes in soil dynamics is monitored by means of satellite images of the area. The change occurs due to various natural factors, such as anthropic ones. A multitemporal study assesses the changes in vegetation cover that existed in the area with the interpretation of satellite images, for instance Landsat, Sentinel 2A, and Spot [76]. Remote sensors gather information from the study area that is physically far from the sensor equipment (satellites or airplanes) that will later be analyzed [77,78]. In the ARE, there are some case studies where remote sensors were applied, such as in the area of deforestation [9], agrarian reforms [79], changes in land use in agricultural-forest landscapes [70], and forest fragmentation [80].

Landsat 7 and 8 satellite images were used because it is the sensor with the greatest application in territorial studies, which includes agriculture, forestry, land use, hydrology, and environmental monitoring [81] (Figure 2). Bands were combined because the spectral range combination means that each band of the satellite image allows one to highlight the characteristics of the area of interest [82]. For example, to highlight the vegetation of a satellite image, the Infrared combination of bands 543 (Landsat 8) or 421 (Landsat 7) needed to be conducted.

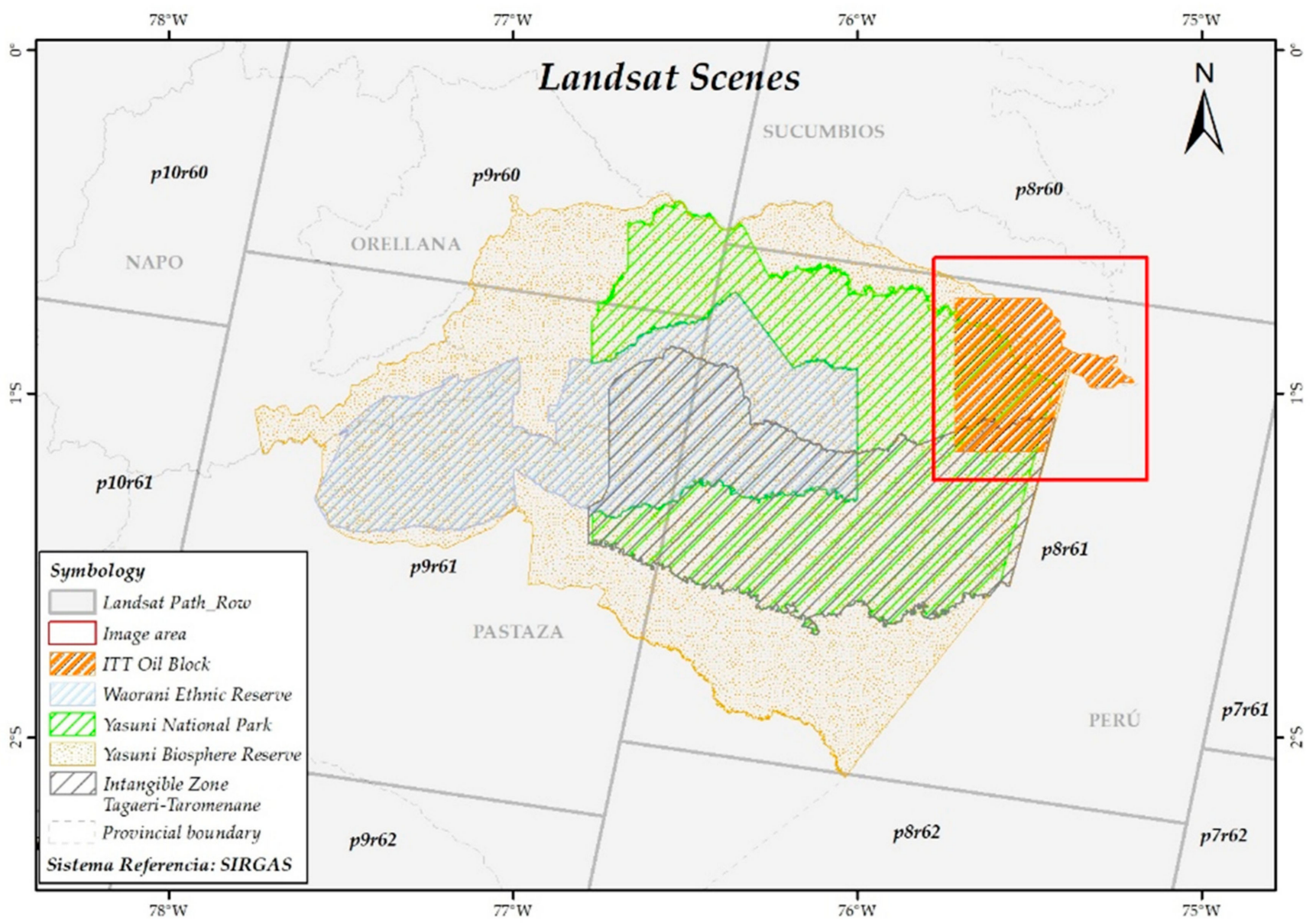

Figure 2. Footprint of satellite images (Landsat 7 and 8) in the ITT Oil Block of the Ecuadorian Amazon region.

Unsupervised classification was used because it is a clustering tool that allows subgroups called clusters within a group and classifies the elements of this group based on the similarity between them [83]. The Normalized Difference Vegetation Index (NDVI) was also used, which is a non-dimensional index that allowed us to measure the relationship between the energy absorbed and emitted from terrestrial objects that, when applied to a group of plants, yield values of intensity concerning greenery and the amount of vegeta- 
tion present in the area as well as its vegetative state ranging from -1 (not forest) to +1 (forest) [84]. Likewise, the raster, calculator raster, and crosstab were used [85,86].

The PCI Geomatic software was used, which processes satellite images from all aerospace platforms (multitemporal analysis) [87], and has two levels: Geomatica core (which classifies satellite images) and Geomatica prime (which has analytical geoprocessing functions). It is also compatible with the ARCGIS software [Carbonnel and Quijada, 2018], which collects, organizes, manages, analyzes, shares, and distributes geographic information [88].

The current study had four main specific objectives: To classify the images from the years 2001, 2014, and 2017; identify existing types of land cover; to quantify changes in land use in the ITT Oil Block of the Amazon; and to characterize the factors associated with the change in land use of the ITT Oil Block. For the fulfillment of these objectives, individual methodological processes were implemented. However, for the first three objectives, the activities in the satellite image processing flow diagram were performed for the three periods (Figure 3).

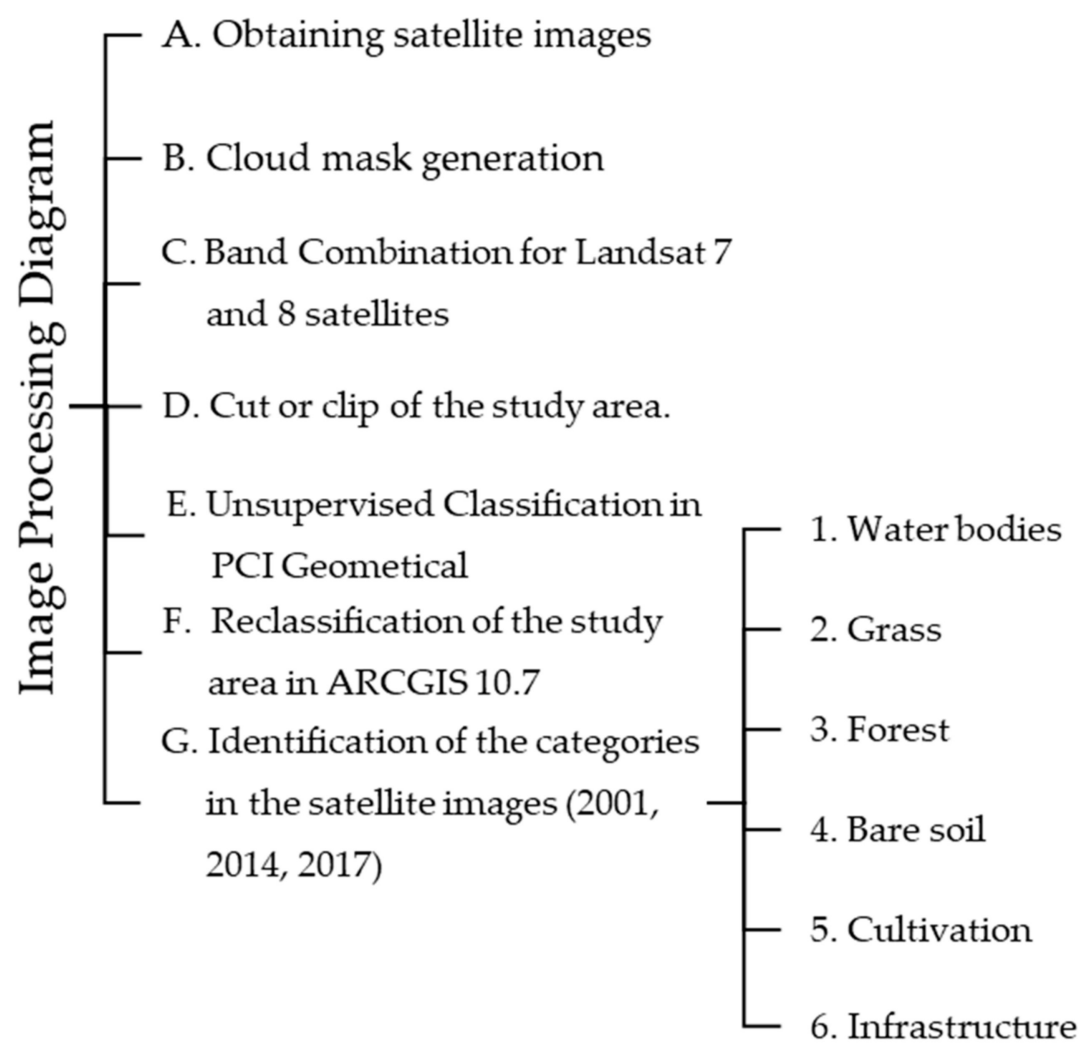

Figure 3. Satellite image processing flow chart for the three periods.

2.2.1. Identification of the Categories in the Satellite Images $(2001,2014,2017)$

(a) Satellite Images

For the analysis of changes in land use, Landsat 7 was used for the year 2001, while Landsat 8 was used for 2014 and 2017 with a spatial resolution of $30 \times 30 \mathrm{~m}$ and a percentage of cloud cover of less than $30 \%$. These were downloaded from the United States Geological Survey (USGS) platform. This format contains all the image bands to make the band combinations.

The downloaded images are of the "L1T" type, thus they have geometric corrections based on control points and digital terrain models [89], with the UTM coordinate system and WGS- 84 reference system in Zone 18 South. The images were processed using the PCI Geomatical application and ARCGIS 10.7. 
The Landsat 8 satellite images for 2018 and 2019 presented a large percentage of cloud cover in the study area. When making cloud layers of the 2019 image, a cut was visualized in the entire northern part of the area of interest, which did not allow a complete analysis of the image so it was replaced by another Landsat 8 image from 2017.

Meanwhile, the Landsat 7 satellite platform presented radiometric and geometric errors on the lateral sides of the images as of 2002, so we worked with the image of the last date in 2001 since it does not have these errors and presents a lower percentage cloudiness in the area of interest.

(b) Cloud mask generation of the satellite images of the different periods

During the analysis of the study area, the satellite images presented clouds, thereby altering the results, so masks of the clouds were realized in the three images of the different periods, giving values of 1 and 0 to the clouds and creating a new raster for combining bands in order for the clouds to be considered a single pixel value [82].

For the creation of cloud masks, the ARCGIS 10.7 program was used, with the bands 2, 3, 4, 5, 6, and 7 of the Landsat 8 satellite image in 2017 (Raster) and the shapefile (Vector) of the study area (ITT Oil Block) in order to locate the area of interest in the generated raster. If clouds were present, a mask of clouds (Mask Cloud) of the period was created. We added the BQA band (band of evaluation or quality control) that has the decimal value of pixels for the clouds.

The Raster Calculator analytical tool was triggered to execute the CON condition (controls the output value for each pixel based on whether the pixel value evaluates to true or false on a specific conditional statement) and the BQA band was added for the purpose of changing the pixel values of the clouds to 0 and 1 with the following algebraic expression:

$$
\text { CON (Band BQA > = Decimal value of the cloud, } 0,1) \text {. }
$$

Then the Raster Calculator was used but with the FLOAT condition (converts the value of each raster pixel into a floating-point representation) and the multiplication of the two bands, with band 2 of the satellite image and the Cloud Mask, with the following equation:

$$
\text { FLOAT ("Band } 2 \text { (Blue)" * "Cloud Mask"). }
$$

The final step of the cloud layer generation process was to save this new raster in the same location as the other Landsat 8 bands of the period with the name "Band 2_cloud".

(c) Process for cutting the study area (ITT Oil Block) from the satellite images in PCI Geomatics

A section was generated of the study area of all the bands of the satellite image for the three periods in order to reduce the processing time of the images when classifying in the PCI Geometics program [82]. Hereby, the PCI Geomatics program was run in its trial version (https: / / www.pcigeomatics.com/resources/more-resources/downloads; accessed date: 24 January 2021) to generate a base meta in a PIX format, adding the bands of the image of the period to be worked on in the layers panel. Then the File option was selected from the menu bar, which displays a list where the Utility option was chosen and then the Import to PCIDSK option. A window opened that gives the options to select the file to import and the destination to save that file. In this case, band 2 (blue) of the Landsat 8 image was selected and saved in the same location as the bands studied.

The same process was conducted again, but instead of selecting the import to the PCIDSK option, 'Transfer layers' was selected to transfer layers from one file to another. In this case, all the utility bands were selected for the analysis, including the new raster generated in the ARCGIS program ("Band 2_cloud") and the transfer option was chosen. After completing the transfer of layers to the new base meta in a PIX format, we selected 'File' from the menu bar and 'open' to open the new base meta generated in the previous process.

The satellite images were cut for the study area using the option 'Clipping/Subsetting' in the Tools menu, which opened a window requesting the base goal to perform this action; 
in this case, the file generated in P2 was chosen. Then the cutting method was selected and 'Selection to Clip Layer' was chosen. The shapefile of the area of interest (ITT Oil Block) was inserted. Finally, the destination to save this cut with the bands and Clip was chosen and a new base meta was generated called "L8_ITT_2017.pix".

(d) Unsupervised Classification Process in PCI Geomatics

The new file generated in the previous process (L8_ITT_2017.pix) was opened with the bands cut from the study area. A new raster was created within the base "L8_ITT_2017.pix" with 32 bits real-time format. When generating this new raster called "CNSITT2017", the unsupervised classification was performed from the Analysis, Image Classification, and Unsupervised options.

From a combination of bands $(2,5,6)$, the unsupervised classification was generated where it was evidenced that categories 1 and 2 have the highest amounts of pixels for 2001 and 2014, while for 2017 it was category 1 and 3 (Table 1; Figure 4).

Table 1. Information on the unsupervised classification in PCI Geomatics for the years 2001, 2014, and 2017 in the ITT Oil Block of the Ecuadorian Amazon region.

\begin{tabular}{ccccccc}
\hline & 2001 & \multicolumn{2}{c}{2014} & \multicolumn{2}{c}{2017} \\
\hline Category & $\begin{array}{l}\text { Number } \\
\text { of Pixels }\end{array}$ & \% Pixels & $\begin{array}{l}\text { Number } \\
\text { of Pixels }\end{array}$ & \% Pixels & $\begin{array}{l}\text { Number } \\
\text { of Pixels }\end{array}$ & \% Pixels \\
\hline 1 & $1,208,527$ & 37.74 & $1,208,527$ & 37.74 & $1,208,527$ & 37.74 \\
2 & $1,648,690$ & 51.48 & $1,318,273$ & 41.17 & 526,605 & 16.44 \\
3 & 275,615 & 8.61 & 6473 & 0.20 & $1,340,573$ & 41.86 \\
4 & 57,896 & 1.81 & 590,469 & 18.44 & 120,889 & 3.77 \\
5 & 11,293 & 0.35 & 78,382 & 2.45 & 5240 & 0.16 \\
6 & 337 & 0.01 & 234 & 0.01 & 524 & 0.02 \\
\hline Total & $3,202,358$ & 100 & $3,202,358$ & 100 & $3,202,358$ & 100 \\
\hline
\end{tabular}
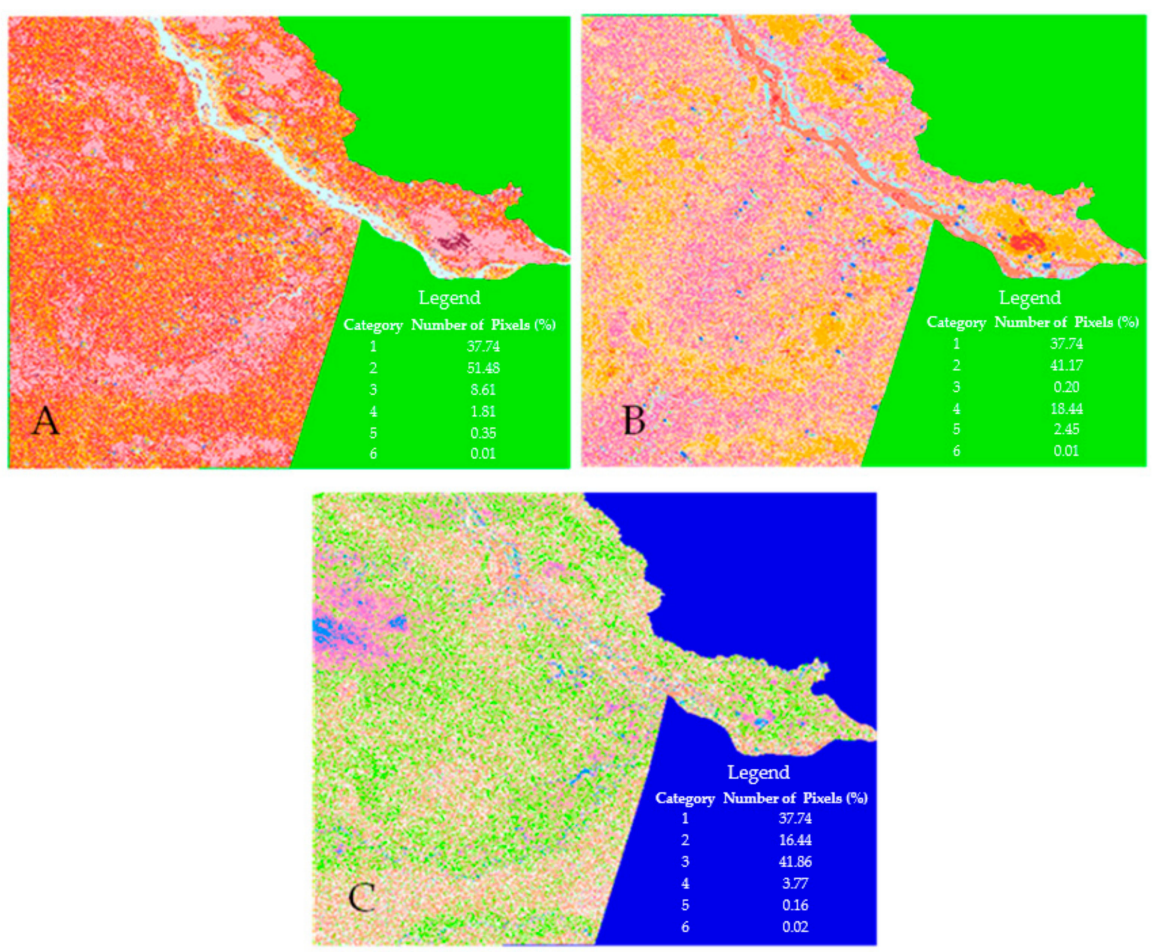

Figure 4. Unsupervised classification of the in the ITT Oil Block of the Ecuadorian Amazon region: (A) 2001; (B) 2014; and (C) 2017 with the PCI Geomatics program. 
A new window was opened that requests the number of classes and a maximum of classifiers. In this project, 24 classes were applied with a maximum of 24 classifiers, considering that for every four pixels, they present similar digital values and we multiplied by the six predefined classes for this area.

Then the selection of bands to be combined and the band to be classified was requested, in this case the following bands were used: B2_clouds (cloud layer), Band 5, and Band 7. For the classification, we used "CNSITT2017" and clicked accept. The unsupervised classification was generated in the "CNSITT2017" raster, which was exported in another PCIDSK (PCI Geomatics Database File) by right-clicking on the classified raster and clicking save/export. It was saved in a new PCIDSK named CNSITT2017.pix with the transfer of the band or raster "CNSITT2017.Tiff".

\subsubsection{Identification of the Types of Land Cover in Each of the Zones}

While obtaining the raster file of the three periods, six categories were identified, namely bodies of water, grassland, forest, bare soil, cultivation, and infrastructure [82]. The bodies of water were categorized by the presence of the Napo river basin and the sub-basins (Aguarico, Nashiño, Yasuní, Tiputini, and Cononaco) [90] in the Aguarico canton where the Tiputini river is located. The grassland was defined based on the use and coverage of the soil. Forest cover was witnessed in the satellite images and because the area has some ecosystems. Bare soil was assigned to roads, non-forest areas, and rock formations. The cultivation was categorized due to the use of the land in the Aguarico canton. Infrastructure was defined as everything that is buildings, homes, platforms, and oil wells (Table 2) [91].

Table 2. Land use and land cover classification scheme in the ITT Oil Block of the Ecuadorian Amazon region.

\begin{tabular}{|c|c|c|}
\hline Categories & Description & Example of Aerial View \\
\hline Bodies of water & $\begin{array}{c}\text { The bodies of water were categorized by the presence of the } \\
\text { Napo River basin and the sub-basins (Aguarico, Nashiño, } \\
\text { Yasuní, Tiputini, and Cononaco) in the Aguarico canton } \\
\text { where the Tiputini river is located. }\end{array}$ & \\
\hline Grassland & $\begin{array}{l}\text { This refers to areas that are not considered agricultural } \\
\text { areas. It also includes areas where the vegetation structure } \\
\text { does not meet the definition of forest land and is expected to } \\
\text { remain so without human intervention. }\end{array}$ & \\
\hline Forest & $\begin{array}{l}\text { A group of trees with a minimum canopy coverage of } 30 \% \text {, } \\
\text { an upper layer height of at least } 5 \mathrm{~m} \text { and a minimum area of } \\
\qquad 10,000 \mathrm{~m}^{2}(1 \mathrm{ha}) .\end{array}$ & \\
\hline
\end{tabular}


Table 2. Cont.

\begin{tabular}{lc} 
Categories & Description \\
\hline Bare soil & Bare soil was assigned to roads, non-forest areas, and rock \\
formations. &
\end{tabular}

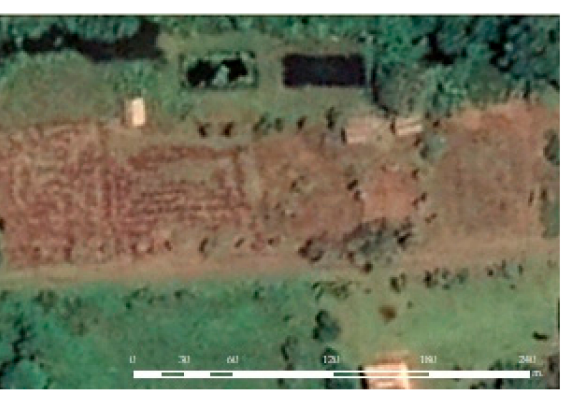

Cultivation

Areas under cultivation, such as monocultures and agroforestry systems where the vegetation structure does not meet the definition of forest land.

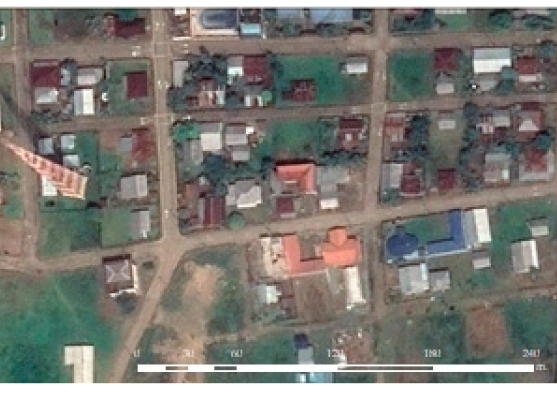

Infrastructure

Infrastructure was defined as houses, other buildings, platforms, and oil wells.

Thus, in the procedure for the reclassification of the ITT from the different periods, the ARCGIS 10.7 program was opened for the reclassification of the new PIX file. For this, the CNSITT2017.pix file was added. For the reclassification of the raster file, reclassify (ArcToolbox/Spatial Analyst Tools/Reclass) was executed. A new window was opened requesting the raster to apply the action, then the classify option was enabled to choose several classification options and the number of classes. In this project, we used equal intervals with six classes. Everything was accepted and the tool was executed.

A new reclassified raster was generated that modifies the colors for each class (Gridcode) depending on the classes proposed for the analysis of this project. Once the classification was made, the Raster to Polygon tool (ArcTollbox/Conversion Tools/From Raster) was executed, allowing us to transform the Raster generated by the reclassification into a polygon (Vector) to perform the area calculation. Once the polygon of the classified study area was generated, the area was calculated. For this, the polygon's attribute table was opened and in the new window that appeared, the Add Field option was chosen, which created a new column previously configured to perform the calculation of their areas in hectares (ha). After this, we right-clicked on the new column and the Calculate Geometry option was selected to obtain the areas in ha.

Polygons with a smaller area were eliminated because there are pixels or errors in the raster image and also because they are not visible on the map and can alter the analysis of the results. In this project, polygons of areas smaller than 2 ha were eliminated using the Eliminate tool (ArcToolbox/Data Management Tools/Generalization). A new polygon was generated, with areas smaller than 2 ha removed, therefore its properties were opened and 
in Symbology we chose Show /Categories panel and in the Value field, "Gridcode" was selected and all the values were added (Add all values). A list of the classes and colors was generated. As an extensive classification among the six classes was generated in P3, and the Dissolve tool was run to reclassify these pixels by their gridcode.

Prior to performing the Dissolve action, some steps needed to be considered. As the classification was generated, the attribute table of the last generated polygon was opened and another column named Dissolve was added. Then, it was selected by attribute. In this case, the Gridcodes of the same color were chosen by means of the expression (Gridcode = the value of the Gridcode of the class) or if there were more classes with the same color, the "OR" condition was added as in this expression (Gridcode = value of the Gridcode of the OR class Gridcode = value of the Gridcode of another OR class) and the amount of Gridcode that belongs to the same class. Later in the attribute table, we clicked on the Dissolve column and the Field Calculator option was selected. A window appeared with a text space at the end that requests the value of this class. In this project there are six classes, so the Gridcodes to be analyzed were given values from 1 to 6 and the unclassified ones (No data) were given values of 0 . Finally, after completing the previous step, the Dissolve tool (ArcToolbox/Data Management Tools/Generalization) was executed, generating a new polygon, but this time with six categories in the attribute table, consisting of the area calculation and the modification of the colors for each category.

All these procedures were applied, for the 3 satellite images in the years 2001, 2014, and 2017 in the study area.

\subsubsection{Quantification of Land-Use Changes in the ITT Oil Block of the Amazon}

\section{(a) Crosstab}

This methodology was applied in order to calculate the difference between the categories of the different periods. That is, the loss or increase in area in hectares of each category was calculated over the years using the ARCGIS 10.7 program with the Tabulate Area tool (ArcToolbox/Spatial Analyst Tools/Zonal). It automatically generated a matrix of the areas of each category in hectares for the three periods [82].

(b) Estimation of the Annual Average Deforestation Rate (AADR)

For the calculation of the annual average of the loss of forest surface between two determined times, the annual average rate of deforestation was applied (Equation (3)) using hectare per year (ha/year) as the unit measurement. The AADR equation is the average annual rate of deforestation:

$$
A A D R_{j t 1-t 2}=\frac{\left(A B_{j t 1}-A B_{j t 2}\right)}{n}
$$

where:

$t_{1}$ is the initial year and $t 2$ is the final year.

$A A D R_{j t 1-j t 2}$ is the average annual rate of deforestation and $\mathrm{j}$ is the moment ( $\mathrm{t} 1$ and $\mathrm{t} 2$ ). $A B_{j t 1}$ is the area covered by forest in the first period.

$A B_{j t 2}$ is the area covered by forest in the second period.

$n$ is the difference of years between both periods.

(a) Estimation of the change rate of land cover and use

The calculation of the rate of change of land cover and use was performed by applying the equation proposed by Puyravaud [92], implemented by Sucoshañay and Corral, (2016).

$$
r=\frac{1}{\left(t_{2}-t_{1}\right)} * \ln \frac{A 2}{A 1} *(100) .
$$

where:

$r$ is the annual rate of change of land cover and use.

$A 1$ is the land-use area in the first period. 
$A 2$ is the land-use area in the final period.

$t_{1}$ is the initial period.

$t_{2}$ is the final period.

\subsubsection{Soil Parameters in ITT Oil Block}

The historical relationship between the periods (2001-2017) was analyzed through a bibliographic review, where those biophysical, demographic, socioeconomic, political, and environmental aspects that have directly or indirectly affected the ITT Oil Block over time are studied.

For the characterization of the factors associated with the change in the use of soil in an ecosystem sensitive to industrial use, secondary information was used, such as a physicalchemical analysis of the soil conducted in the Tiputini and Tambococha platform area by the public company Petroamazonas in 2011, where the parameters Total Hydrocarbons (TPH), Polycyclic Aromatic Hydrocarbons (HAPAs), Cadmium (Cd), Nickel (Ni), and Lead $(\mathrm{Pb})$ were analyzed in order to verify the permissible limits for sensitive ecosystems (Reglamento Ambiental de Operaciones Hidrocarburíferas, 2020). Table 3 indicates detailed permissible limits of the Tambococha soil [93].

Table 3. Permissible soil limits in the ITT Oil Block of the Ecuadorian Amazon region.

\begin{tabular}{cccc}
\hline Parameter & Unit & Sensitive Ecosystem & Industrial Use \\
\hline $\mathrm{TPH}$ & $\mathrm{mg} / \mathrm{kg}$ & $<1000$ & $<4000$ \\
$\mathrm{HAPs}$ & $\mathrm{mg} / \mathrm{kg}$ & $<1$ & $<5$ \\
$\mathrm{Cd}$ & $\mathrm{mg} / \mathrm{kg}$ & $<1$ & $<10$ \\
$\mathrm{Ni}$ & $\mathrm{mg} / \mathrm{kg}$ & $<80$ & $<100$ \\
$\mathrm{~Pb}$ & $\mathrm{mg} / \mathrm{kg}$ & $<500$ \\
\hline
\end{tabular}

\section{Results and Discussion}

\subsection{Unsupervised Classification of the ITT Oil Block}

The classification of the images was unsupervised because the study area is militarized and it is forbidden to fly aircraft and drones over it. The unsupervised classification was performed with the PCI Geomatics tool based on Melo [94]. Hereby, we compared the processing performance and classification of images between ARCGIS 10.7 and PCI Geomatica. The latter turned out to be better in runtime, image loading time, display, intermediate process time, etc. It was concluded that it is faster and more efficient, and the classification process was compared to ARCGIS 10.7. In another multitemporal study [83] on fire recurrence areas that was conducted in the Metropolitan District of Quito, they recommended the application of this methodology for the treatment of satellite images that is of importance for analysis and the geometric and radiometric corrections of the image need to be considered previously. Subsequently, they applied unsupervised classification for the respective digitization.

\subsection{Identification of the Types of Land Cover in Each of the Zones}

For the analysis of changes in land use, six categories were identified: Bodies of water, grassland, forest, bare soil, cultivation, and infrastructure. In the classification of the 2001 period, the forest category presented the highest number of pixels, followed by grassland and bodies of water. Those with the least number of pixels were cultivation, soil, and infrastructure. The latter was visualized in the surroundings of the bodies of water category and we observed large forest cover in the ITT Oil Block (Figure 5). 

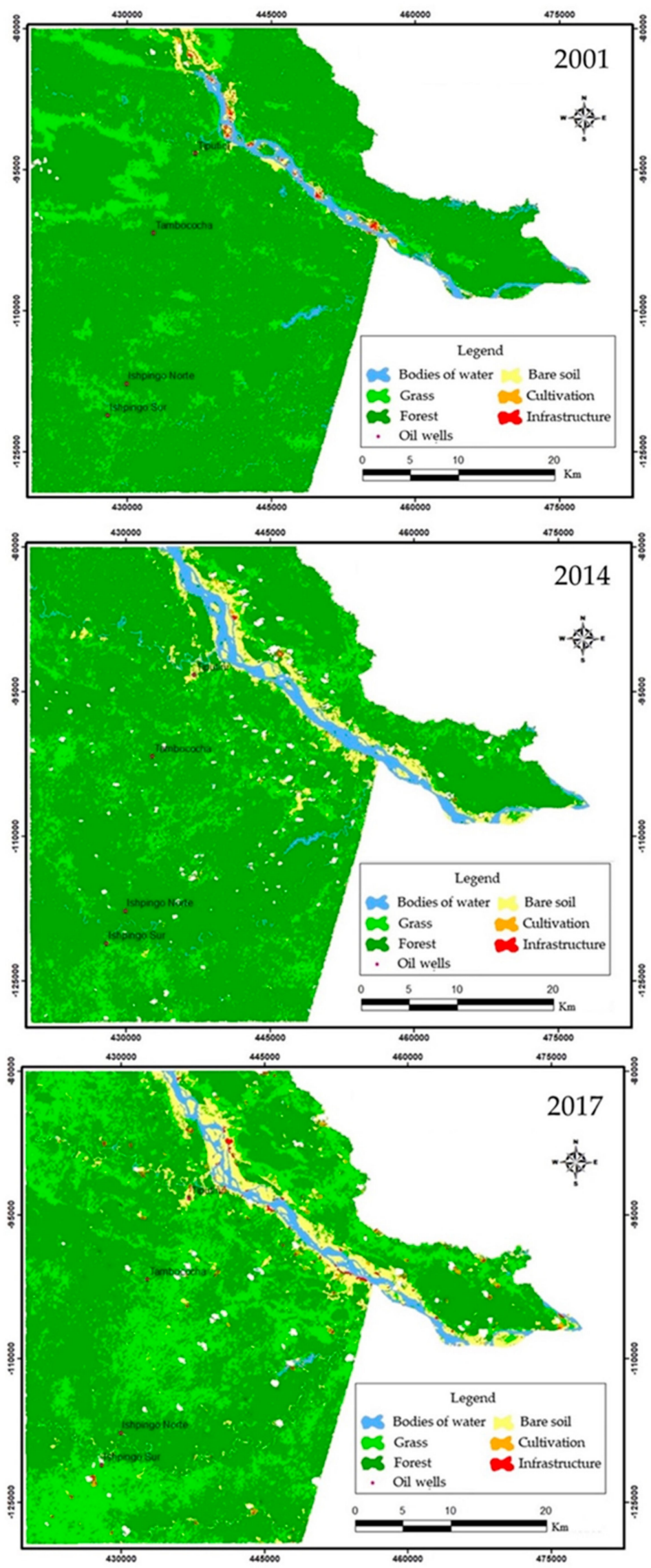

Figure 5. Classification of land-use changes in the ITT Oil Block of the Ecuadorian Amazon region in the years 2001 (upper part), 2014 (center), and 2017 (lower part). 
For the classification of the 2014 period, the forest category presented the highest number of pixels, followed by grassland, soil, and bodies of water. Those with the least number of pixels were cultivation and infrastructure. An extension of soil was visualized on the shores of the body of water in the ITT Oil Block and a lower amount of infrastructure than in the previous period (Figure 5 center). For the classification of the 2017 period, the grassland category presented the highest number of pixels, followed by forest, soil, and bodies of water. Those with the least number of pixels were cultivation and infrastructure. It was visualized that the soil category had expanded with respect to the two previous periods and that the forest category decreased enormously (Figure 5 lower part).

In a similar study conducted in the south of the Napo province, in the Tena canton, on the banks of the Napo river, the following units were defined, being forest, urbanized areas, agricultural mosaic (coverage made up of associations between different types of crops), predominance of pastures and crops (areas of predominance of grass-type species and short-cycle crops), and bodies of water [70].

\subsection{Quantification of Land-Use Changes in the ITT Oil Block of the Amazon}

The changes in land use in the ITT of the Ecuadorian Amazon in the three periods were quantified using the Cross Tabulation methodology (Table 4). In 2001, the forest area (primary and secondary) covered $149,330.16$ ha $(83.22 \%)$ of the $179,449.53$ ha of the total area of the ITT area. Bare sole in the ITT made up 2515.26 ha $(1.40 \%)$ and agriculture made up 184.66 ha $(0.10 \%)$. By 2014 , the forest had decreased to $137,157.12$ ha $(76.43 \%)$, while bare soil increased to 7796.61 ha $(4.34 \%)$, as did cultivation to 427.68 ha $(0.24 \%)$. By the third period (2017), the forest had decreased to $105,846.69$ ha $(58.98 \%)$, whereas bare soil increased to $10,640.82$ ha (5.93\%) and cultivation to 591.29 ha (0.33\%) (Figure 6).

Table 4. Area in hectares for each category in the ITT Oil Block of the three periods.

\begin{tabular}{ccccccccc}
\hline $\begin{array}{c}\text { Periods } \\
\text { Categories }\end{array}$ & Ha & $\mathbf{2 0 0 1}$ & $\mathbf{\%}$ & Ha & $\mathbf{\%}$ & Ha & \% & $\begin{array}{c}\text { Total } \\
\text { (2001-2017) }\end{array}$ \\
\hline $\begin{array}{c}\text { Bodies of } \\
\text { water }\end{array}$ & 5379.38 & 2.99 & 6329.97 & 3.53 & 4379.39 & 2.44 & 999.99 \\
Grass & $20,917.34$ & 11.66 & $24,530.50$ & 13.67 & $55,064.2$ & 30.69 & $-34,146.89$ & -19.03 \\
Forest & $149,330.20$ & 83.22 & 137,157 & 76.43 & 105,847 & 58.98 & $43,483.47$ & 24.23 \\
Bare soil & 2515.26 & 1.40 & 779,661 & 4.35 & $10,640.80$ & 5.93 & -8125.56 & -4.53 \\
Cultivation & 184.66 & 0.103 & 427.68 & 0.238 & 591.29 & 0.33 & -406.63 & -0.23 \\
Infrastructure & 311.69 & 0.174 & 54.81 & 0.031 & 803.85 & 0.448 & -492.16 & -0.27 \\
\hline
\end{tabular}

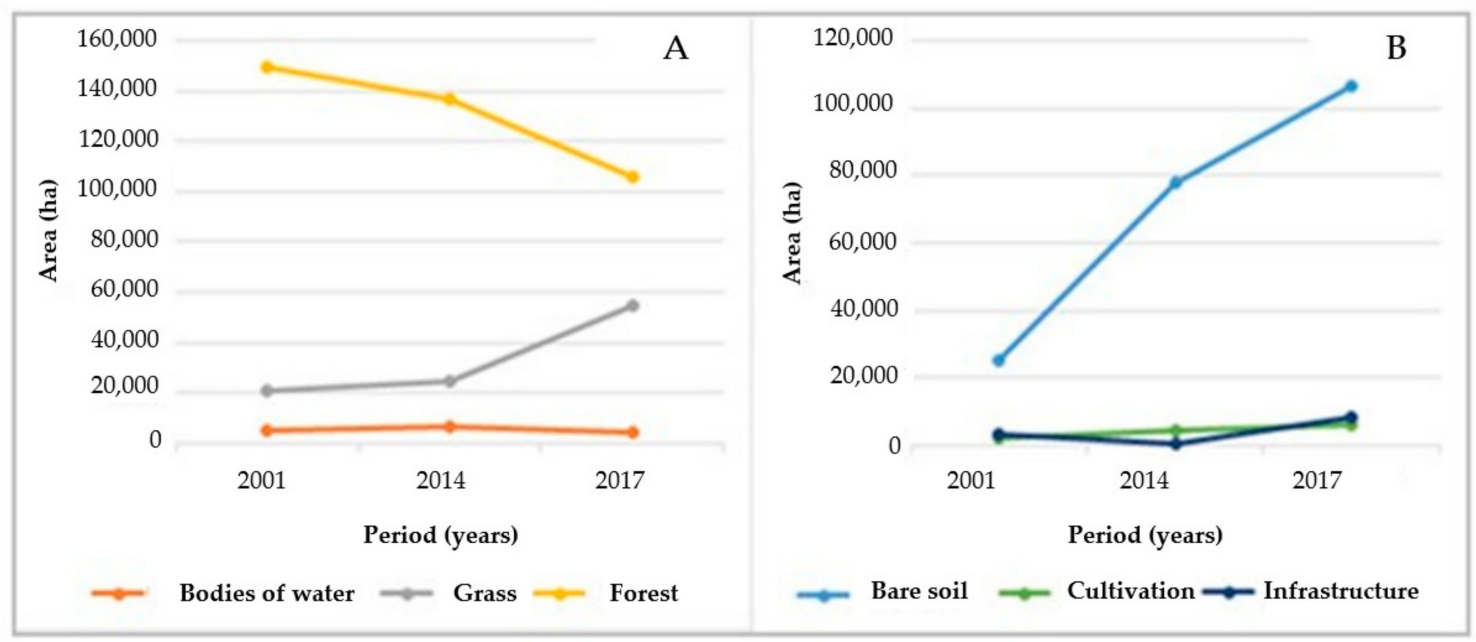

Figure 6. Spatial dynamics of the categories: (A) Bodies of water, grassland, and forest; (B) bare soil, cultivation, and infrastructure in the ITT Oil Block. 
Upon comparing the years 2001 and 2017 in the ITT Oil Block, it is clear that over the 16 years there were greater changes in land use within bodies of water as it lost $0.56 \%$ ( 999.99 ha). Meanwhile, pasture increased by $19.03 \%$ (34,146.89 ha), forests decreased by $24.23 \%$ ( $43,483.47 \mathrm{ha})$, soil increased by $4.53 \%(8,125.56 \mathrm{ha})$, and cultivation increased by $0.23 \%(406.63 \mathrm{ha})$. This is due to the fact that infrastructure increased in the area, occupying $0.27 \%$ (803.85 ha) in 2017 (Table 4).

This quantification of hectares for each category was taken as a reference for the image of the year 2001, which served as the basis for calculating the annual average rate of deforestation and rate of changes in land cover and use in the other two years of interest.

Furthermore, Equation (3) was applied in order to analyze the average annual deforestation rate in the ITT Oil Block for the 2014 and 2017 periods in the Ecuadorian Amazon, taking the 2001 period as the basis of analysis. Thus, the deforestation rate for the period 2001-2014 was calculated, which was 936.39 ha/year (5). This is equivalent to $0.63 \%$ compared to the original forest that existed in the 2001 period (Table 5).

$$
\begin{gathered}
\operatorname{AADR}_{(2001-2014)}=\frac{\left(A B_{(2001)}-A B_{(2014)}\right)}{n} \\
A A D R_{(2001-2014)}=\frac{(149,330.16-137,157.12)}{13} \\
\operatorname{AADR}_{(2001-2014)}=936.39 \mathrm{ha} / \text { year. }
\end{gathered}
$$

Table 5. Deforestation rate in the ITT Oil Block of the Ecuadorian Amazon region.

\begin{tabular}{cc}
\hline Period & Annual Deforestation Rate (ha/Year)/(\%) \\
\hline $2001-2014$ & $936.39(0.627)$ \\
$2001-2017$ & $2717.71(1.82)$ \\
\hline
\end{tabular}

The deforestation rate for the period 2001-2017 was calculated at $2717.71 \mathrm{ha}$ /year (6), which is equivalent to $1.82 \%$ with respect to the original forest that existed in the 2001 period (Table 5).

$$
\begin{gathered}
A A D R_{(2001-2017)}=\frac{\left(A B_{(2001)}-A B_{(2017)}\right)}{n} \\
A A D R_{(2001-2017)}=\frac{(149,330.16-105,846.69)}{16} \\
A A D R_{(2001-2017)}=2717.71 \mathrm{ha} / \text { year. }
\end{gathered}
$$

\subsection{Characterization of the Factors Associated with the Change in Land Use of the ITT Oil Block}

The rate of land cover and use changes in the ITT Oil Block was calculated using Equation (4), based on the anthropogenic activities that existed in the ITT Oil Block. In the years 2001, 2014, and 2017, the results determined that land use tended to decrease the vegetation cover. In other words, the deforestation rate of the ITT Oil Block, located in the upper part, was $2.15 \%$. The worst affected zones were those in the vicinity of the populated areas and the Napo River Basin. During the period studied, cultivation had the second-highest rate of change at $7.27 \%$. In terms of extension, bare soil is the most representative in the ITT Oil Block with a percentage of 9.01\% (Table 6).

In a similar study carried out in the Puyo River Basin in the Ecuadorian Amazon, the same equation was implemented [92]. The results of that research between the periods 2000, 2004, and 2013 were that land use has a tendency to decrease forest cover (the deforestation rate was $4 \%$ ), especially in areas close to mountains. Moreover, the increase in cultivation near rural areas (4\%) showed the productive evolution of the study area. In addition, the increase in areas without vegetation cover and populated areas was evident [95]. 
Table 6. Annual rate of change of land cover and use in the ITT Oil Block of the Ecuadorian Amazon region for the period 2001-2017.

\begin{tabular}{cccc}
\hline Categories & $\mathbf{2 0 0 1}$ & $\mathbf{2 0 1 7}$ & $\begin{array}{c}\text { Land-Use Change Rate } \\
\text { (ha)/(\%) }\end{array}$ \\
\hline Bodies of the water & 5379.38 & 4379.39 & $-0.01 /-1.29$ \\
Grass & $20,917.34$ & $55,064.23$ & $0.06 / 6.05$ \\
Forest & $149,330.16$ & $105,846.69$ & $-0.02 /-2.15$ \\
Bare soil & 2515.26 & $10,640.82$ & $0.09 / 9.01$ \\
Cultivation & 184.66 & 591.29 & $0.07 / 7.27$ \\
Infrastructure & 311.69 & 803.85 & $0.06 / 5.92$ \\
\hline
\end{tabular}

\subsection{Soil Parameters in ITT Oil Block}

A bibliographic review was performed in order to understand the incidents on each of the categories that were analyzed in the ITT Oil Block during the three given periods. In 2001, the bodies of water category represented 2.99\% (5379.38 ha), but in 2014, it increased to $3.52 \%$ (6329.97 ha). This occurred due to several aspects, such as the movement of streams and the increase in flow and erosion along the banks [96]. Regarding infrastructure, in 2001 it had a surface area of $0.174 \%$ (311.69 ha) and there were some homes near the Napo River, but in 2014 it decreased, occupying 0.031\% (311.69 ha). This happened due to the high rainfall in the Province of Orellana, which generated flooding along the Napo River, and as its water storage capacity was saturated in the middle basin, causing floods (greater than $5000 \mathrm{~m}^{3} / \mathrm{s}$ ) on 6 April 2010 [97]. The changes in land use in the ARE occurred due to the implementation of public policies to control and access Amazonian spaces, the extraction of natural resources, and agriculture [98].

Deforestation and changes in land use occur due to human activities such as agriculture, livestock, and human settlements [99]. According to INEC [67], the number of inhabitants in the Aguarico canton in 2001 was 4658, whereas in 2010 it was 4847, that is, it increased by $0.42 \%$, which means that the population expanded throughout the Amazon basin, decreasing the forest cover of the area to 105,847 ha, $58.98 \%$ of what it had been in 2001 (149,330.2 ha). In a study conducted in the northern Ecuadorian Amazon, which covers the Sucumbíos, Orellana, and Napo provinces, deforestation was caused by two reasons, the discovery of oil and construction of ballasted and unburdened roads to transport oil by pipelines to Esmeraldas (the Pacific coast) for export, and secondly the migration of rural populations from the Sierra region caused by the need for land [100]. In the 1960s, oil reserves were discovered in the northern Ecuadorian Amazon, which accelerated the processes of colonization of new areas in the lowlands [37]. Previous studies demonstrated that the activities generated by the oil companies and the construction of roads were the main causes because they promoted deforestation and agricultural settlements in the ARE [68].

The strongest dynamics of land-use changes between 2001 and 2017 was concentrated along the banks of the Napo and Yasuní rivers. This probably occurred due to the urban population growth in Tiputini and Rocafuerte [101]. The intensification of agricultural activities that existed in the ITT Oil Block was reflected in 2014, occupying an area of 427.68 ha, which represents $0.23 \%$ of the ITT Oil Block. In 2017, it increased to 591.29 ha $(0.329 \%)$. This is due to small farm producers, who incorporate the forested area into agricultural production, thus becoming the main factor in deforestation and degradation in the area [102].

With respect to the physical-chemical analysis of the soil performed in 2011 and 2015 in the Tiputini and Tambococha platform area, it was evidenced that the following parameters were way above the limits allowed by Ecuadorian legislation in the Tambococha area: The TPH, Cd, and $\mathrm{Pb}$ in 2011, and TPH, HAPs, and Pb in 2015. TPH, HAPs, and Cd also exceeded permissible limits in Tiputini in 2015 (Tables 7 and 8). If environmental measures are not applied that allow people to prevent, avoid, and control the use of land, the sensitive ecosystem will change to 'industrial land use', thereby losing the existing 
biodiversity in the area, such as species like Podocnemis expansa, which is in a critical condition, hence it is on Ecuador's red list.

Table 7. Results of the physical-chemical analysis in the Tambococha area. The first results are from EIA and PMA (code B1), the second from ACT. EIA and PMA (code B1), and soil quality criteria are from AM 097 -A (Table 1) [103], based on the Environmental Impact Study 2011 [104] and Update on the Environmental Impact Study Project Development and Production of the Tiputini and Tambococha Fields 2015 [105].

\begin{tabular}{cccccc}
\hline Parameter & Unit & 2011 Result & 2015 Result & $\begin{array}{c}\text { Soil Quality } \\
\text { Criterium }\end{array}$ & Observation \\
\hline $\mathrm{TPH}$ & $\mathrm{mg} / \mathrm{kg}$ & 1470 & $<100$ & $<150$ & Fails \\
\hline $\mathrm{HAPs}$ & $\mathrm{mg} / \mathrm{kg}$ & 0.053 & $<0.364$ & 0.1 & Complies in 2011 \\
\hline $\mathrm{Cd}$ & $\mathrm{mg} / \mathrm{kg}$ & $<2$ & $<0.500$ & 0.5 & Does not comply in 2015 \\
\hline $\mathrm{Ni}$ & $\mathrm{mg} / \mathrm{kg}$ & 3 & $<10.0$ & 19 & Coes not comply in 2011 \\
\hline $\mathrm{Pb}$ & $\mathrm{mg} / \mathrm{kg}$ & 78 & 13.5 & 19 & Does not comply in 2011 \\
\hline
\end{tabular}

Table 8. Results of the physical-chemical analysis of the Tiputini area. The first results are from EIA and PMA (code B1) and soil quality criteria are from AM097 -A (Table 1) [103], based on the Environmental Impact Study 2011 [104] and Update on the Environmental Impact Study Project Development and Production of the Tiputini and Tambococh Fields [105].

\begin{tabular}{ccccc}
\hline Parameter & Unit & 2011 Result & $\begin{array}{c}\text { Soil Quality } \\
\text { Criteria }\end{array}$ & Observation \\
\hline $\mathrm{TPH}$ & $\mathrm{mg} / \mathrm{kg}$ & 3801 & $<150$ & Fails \\
$\mathrm{HAPs}$ & $\mathrm{mg} / \mathrm{kg}$ & 0.11 & 0.1 & Fails \\
$\mathrm{Cd}$ & $\mathrm{mg} / \mathrm{kg}$ & $<2$ & 0.5 & Fails \\
$\mathrm{Ni}$ & $\mathrm{mg} / \mathrm{kg}$ & 2 & 19 & Complies \\
$\mathrm{Pb}$ & $\mathrm{mg} / \mathrm{kg}$ & $<9$ & 19 & Complies \\
\hline
\end{tabular}

3.6. Possible Political Implications for Restoration and Planning in the ITT Oil Block of the Ecuadorian Amazon Region

Local and regional entities should promote projects to improve human well-being and the restoration of ecosystems in the ITT Oil Block using $4 \%$ of the funds of the sale price for each oil barrel. This has been arranged to invest in the areas of influence of oil, mining, and electricity exploitation projects according to the Organic Law for the Integral Planning of the Amazon, Special Territorial Circumscription [106]. This law, approved by the National Assembly of Ecuador and published in the Official Register Supplement 245 on 21 May 2018, is fundamental for administrative and environmental legislation, as it seeks to increase and diversify production, promote technology transfer, strengthen comprehensive security, and generate opportunities in the Amazon region [107].

It is essential to seek an unprecedented global governance mechanism that promotes environmental justice and is an innovative development proposal. Oil extraction is a useful perspective to think and write about in regards to the future of the use of resources, which seeks to achieve the sustainability of the Ecuadorian Amazon region.

Considering the global importance of the RBY and the Amazon basin in terms of conserving its high diversity, the findings of this research contribute to reformulating a governance model for the ITT oil block, similar to the one carried out for the Diversity and Life Zone, which has been established by national and local organizations public organizations [108] that aim to (a) strengthen governance; (b) achieve a balance between the conservation of the environment and living conditions; and (c) rescue cultural dynam- 
ics. A new management model for the ITT oil block would be implemented through a special regime that guarantees sustainability and minimizes risk factors for indigenous communities and migrant settlers, with greater emphasis on biodiversity [109].

\section{Conclusions}

The unsupervised classification of the images allowed the visualization of variations of vegetation cover, hydrographic basins, and soils of the ITT Oil Block of the Ecuadorian Amazon through the automatic use of tools, such as PCI Geomatic and ARCGIS without the need to visit the study area. In the current investigation, as it is an area of national interest, certain areas cannot be accessed and flying objects (drones and airplanes) are prohibited in the area, so satellite images from the periods of 2001, 2014, and 2017 were used.

The study area was classified into six categories, where the infrastructure was identified by geometric shapes and colors that have a group of pixels of the same values, while agricultural lands were made up of geometric shapes of a larger area and were generally around rural areas and populated areas existing in the ITT.

The changes in land use in the ITT Oil Block were quantified and it was analyzed that in 16 years, there have been variations in the area. In global terms, the category of forests decreased, and bare soil and cultivation increased. The deforestation rate determined respectively between 2001 and 2014 and between 2014 and 2017 was $1.82 \%$ and $2.15 \%$, which makes the general average an annual deforestation rate of $2 \%$ in the ITT Oil Block in the period 2000-2017.

The change in vegetation cover was due to two factors that are natural and anthropic. The natural factor was rainfall in the province of Orellana, which caused flooding throughout the middle basin of the Napo River, affecting houses near the river and demographic change. One anthropic factor was population growth in the area, which over time expanded demographically due to rural populations coming from other regions in search of new lands and intensifying agricultural activities to improve their quality of life and economy, which impacted the landscape. Oil was another factor due to the construction of ballasted and unballasted roads for the transport of oil by pipelines for export.

Finally, in 2011 and 2015 in the Tiputini and Tambococha platform area, it was evidenced that the critical parameters of TPH, HAPs, $\mathrm{Cd}$, and $\mathrm{Pb}$ have been predominantly above the limits allowed by Ecuadorian legislation, changing the use of sensitive ecosystem land to industrial land use within a sensitive biological area.

Author Contributions: Conceptualization: M.H.-R., C.S., and T.T.; methodology: M.H.-R., C.S., D.B., and T.T.; software: M.H.-R., C.S., and P.P.; writing—original draft preparation: M.H.-R., C.S., T.T., P.P., J.C., and G.V.; writing-review and editing: M.H.-R., J.C., P.P, G.V., and T.T. All authors have read and agreed to the published version of the manuscript.

Funding: This research has not received funds.

Institutional Review Board Statement: Not applicable.

Informed Consent Statement: Not applicable.

Data Availability Statement: To access the data supporting the results found, please contact the corresponding author.

Acknowledgments: The authors would like to thank the Universidad de las Fuerzas Armadas (ESPE), Sangolquí, Ecuador, for its inter-institutional collaboration to carry out this research in its computer systems laboratories.

Conflicts of Interest: The authors declare no conflict of interest.

\section{References}

1. Wright, S.J.; Muller-Landau, H.C. The Future of Tropical Forest Species1. Biotropica 2006, 38, 287-301. [CrossRef]

2. Karjalainen, E.; Sarjala, T.; Raitio, H. Promoting human health through forests: Overview and major challenges. Environ. Health Prev. Med. 2010, 15, 1. [CrossRef] [PubMed] 
3. Chakravarty, S.; Ghosh, S.K.; Suresh, C.P.; Dey, A.N.; Shukla, G. Deforestation: Causes, effects and control strategies. Glob. Perspect. Sustain. For. Manag. 2012, 1, 1-26.

4. Inyang, M.P.; Esohe, K.P. Deforestations, environmental sustainability and health implications in Nigeria: A review. Int. J. Sci. Environ. Technol. 2014, 3, 502-517.

5. Landsberg, H.E. Man-Made Climatic Changes: Man's activities have altered the climate of urbanized areas and may affect global climate in the future. Science 1970, 170, 1265-1274. [CrossRef] [PubMed]

6. Dick, H. The oil price subsidy, deforestation and equity. Bull. Indones. Econ. Stud. 1980, 16, 32-60. [CrossRef]

7. Henderson-Sellers, A.; Gornitz, V. Possible climatic impacts of land cover transformations, with particular emphasis on tropical deforestation. Clim. Chang. 1984, 6, 231-257. [CrossRef]

8. Kar, N.P.; Kumar, A.; Singh, O.P.; Carlton, J.M.; Nanda, N. A review of malaria transmission dynamics in forest ecosystems. Parasites Vectors 2014, 7, 265. [CrossRef] [PubMed]

9. Heredia-R, M.; Torres, B.; Cabrera-Torres, F.; Torres, E.; Díaz-Ambrona, C.G.H.; Pappalardo, S.E. Land Use and Land Cover Changes in the Diversity and Life Zone for Uncontacted Indigenous People: Deforestation Hotspots in the Yasuní Biosphere Reserve, Ecuadorian Amazon. Forests 2021, 12, 1539. [CrossRef]

10. Gilruth, P.T.; Hutchinson, C.F. Assessing Deforestation in the Guinea Highlands of West Africa Using Remote. Photogramm. Eng. Remote Sens. 1990, 56, 1375-1382.

11. Southgate, D.; Whitaker, M. Promoting resource degradation in Latin America: Tropical deforestation, soil erosion, and coastal ecosystem disturbance in Ecuador. Econ. Dev. Cult. Chang. 1992, 40, 787-807. [CrossRef]

12. Walsh, J.F.; Molyneux, D.H.; Birley, M.H. Deforestation: Effects on vector-borne disease. Parasitology 1993, 106, S55-S75. [CrossRef]

13. Patz, J.A.; Gibbs, H.K.; Foley, J.A.; Rogers, J.V.; Smith, K.R. Climate change and global health: Quantifying a growing ethical crisis. EcoHealth 2007, 4, 397-405. [CrossRef]

14. Poffenberger, M. Cambodia's forests and climate change: Mitigating drivers of deforestation. In Natural Resources Forum; Blackwell Publishing Ltd.: Oxford, UK, 2009; Volume 33, pp. 285-296.

15. Kim, D.H.; Sexton, J.O.; Townshend, J.R. Accelerated deforestation in the humid tropics from the 1990s to the 2000s. Geophys. Res. Lett. 2015, 42, 3495-3501. [CrossRef] [PubMed]

16. Padilla, O.; Rosas, P.; Moreno, W.; Toulkeridis, T. Modeling of the ecological niches of the anopheles spp in Ecuador by the use of geo-informatic tools. Spat. Spatio-Temporal Epidemiol. 2017, 21, 1-11. [CrossRef] [PubMed]

17. Barreto-Álvarez, D.E.; Heredia-Rengifo, M.G.; Padilla-Almeida, O.; Toulkeridis, T. Multitemporal Evaluation of the Recent Land Use Change in Santa Cruz Island, Galapagos, Ecuador. In Proceedings of the Conference on Information and Communication Technologies of Ecuador, Guayaquil, Ecuador, 25-27 November 2020; Springer: Cham, Switzerland, 2020; pp. 519-534.

18. Carrera, M.B.B.; Almeida, O.P.; Toulkeridis, T. Modeling of the spatial distribution of the vector Aedes Aegypti, transmitter of the Zika Virus in continental Ecuador by the application of GIS tools. Bionatura 2020, 5, 1314-1327. [CrossRef]

19. Arellano-Pérez, K.; Padilla-Lascano, P.; Molina-Sánchez, I.; Padilla-Almeida, O.; Toulkeridis, T. Evaluation of The Surface Temperature Applied in Aquaculture Based on Satellite Images in Coastal Ecuador. In Proceedings of the Conference on Information and Communication Technologies of Ecuador, Guayaquil, Ecuador, 25-27 November 2020; Springer: Cham, Switzerland, 2020; pp. 572-586.

20. Zeppetello, L.R.V.; Parsons, L.A.; Spector, J.T.; Naylor, R.L.; Battisti, D.S.; Masuda, Y.J.; Wolff, N.H. Large scale tropical deforestation drives extreme warming. Environ. Res. Lett. 2020, 15, 084012. [CrossRef]

21. Gatti, L.V.; Basso, L.S.; Miller, J.B.; Gloor, M.; Gatti Domingues, L.; Cassol, H.L.; Neves, R.A. Amazonia as a carbon source linked to deforestation and climate change. Nature 2021, 595, 388-393. [CrossRef]

22. Silva, M.J.; Costa, M.F.D.; de Farias, S.A.; Wanderley, L.S. Who is going to save the Brazilian Amazon forest? Reflections on deforestation, wildlife eviction, and stewardship behavior. Psychol. Mark. 2020, 37, 1720-1730. [CrossRef]

23. Nivithra, S.; Shoba Jasmin, K.S. A Study on Social Awareness about Deforestation in India. Environ. Policy Law 2020, 50, 411-414. [CrossRef]

24. Ma'arij, A.; Ridwan, R.; Firdaus, M.; Sukirman, S. Deforestation and Disaster Mitigation: Policy Analysis for the Prevention and Enforcement of Forest Function Change in Bima. Forest 2020, 258, 23-218.

25. Assa, B.S.K. The deforestation-income relationship: Evidence of deforestation convergence across developing countries. Environ. Dev. Econ. 2021, 26, 131-150. [CrossRef]

26. Malhi, Y.; Roberts, J.T.; Betts, R.A.; Killeen, T.J.; Li, W.; Nobre, C.A. Climate change, deforestation, and the fate of the Amazon. Science 2008, 319, 169-172. [CrossRef] [PubMed]

27. Malhi, Y.; Aragão, L.E.; Galbraith, D.; Huntingford, C.; Fisher, R.; Zelazowski, P.; Meir, P. Exploring the likelihood and mechanism of a climate-change-induced dieback of the Amazon rainforest. Proc. Natl. Acad. Sci. USA 2009, 106, 20610-20615. [CrossRef] [PubMed]

28. Ometto, J.P.; Aguiar, A.P.D.; Martinelli, L.A. Amazon deforestation in Brazil: Effects, drivers and challenges. Carbon Manag. 2011, 2, 575-585. [CrossRef]

29. Strand, J.; Carson, R.T.; Navrud, S.; Ortiz-Bobea, A.; Vincent, J.R. Using the Delphi method to value protection of the Amazon rainforest. Ecol. Econ. 2017, 131, 475-484. [CrossRef]

30. Murad, C.A.; Pearse, J. Landsat study of deforestation in the Amazon region of Colombia: Departments of Caquetá and Putumayo. Remote Sens. Appl. Soc. Environ. 2018, 11, 161-171. [CrossRef] 
31. Tapia-Armijos, M.F.; Homeier, J.; Espinosa, C.I.; Leuschner, C.; de la Cruz, M. Deforestation and forest fragmentation in South Ecuador since the 1970s-losing a hotspot of biodiversity. PLOS ONE 2015, 10, e0133701. [CrossRef]

32. Van Marle, M.J.E.; Van Der Werf, G.R.; De Jeu, R.A.M.; Liu, Y.Y. Annual South American forest loss estimates based on passive microwave remote sensing (1990-2010). Biogeosciences 2016, 13, 609-624. [CrossRef]

33. Armenteras, D.; Espelta, J.M.; Rodríguez, N.; Retana, J. Deforestation dynamics and drivers in different forest types in Latin America: Three decades of studies (1980-2010). Glob. Environ. Chang. 2017, 46, 139-147. [CrossRef]

34. Duque-Rengel, V.K.; Heredia-R, M.; Calva-Cabrera, K.D.; Torres, B.; Toulkeridis, T. Climate Governance and Sustainable Development: A Sight to the Intermediate and Border Cities of Ecuador. In Proceedings of the International Conference on Water Energy Food and Sustainability, Leiria, Portugal, 10-12 May 2021; Springer: Cham, Switzerland, 2021; pp. 646-655.

35. Rivas, C.A.; Guerrero-Casado, J.; Navarro-Cerillo, R.M. Deforestation and fragmentation trends of seasonal dry tropical forest in Ecuador: Impact on conservation. For. Ecosyst. 2021, 8, 46. [CrossRef]

36. Le Quang, M. El sentido político de la Iniciativa Yasuní-ITT: Disputa entre capitalismo verde y ecosocialismo. THEOMAI J. 2015, 32, 75-94.

37. Borja, M.O.; Aragón-Osejo, J.; Josse, C. Bosques de la Región Amazónica Ecuatoriana: ¿Qué nos dicen las cifras de deforestación de los últimos 15 años? In CONFIBSIG, eje 2: Recursos Naturales, Ambiente y Cambio Climático; Universidad del Azuay: Azuay, Ecuador, 2017.

38. Petroamazonas, E.P. Reporte Gerencial. 2017. Available online: https://www.petroamazonas.gob.ec/wp-content/uploads/ downloads/2018/04/Reporte_Gererencial_2017_Final1.pdf (accessed on 26 May 2021).

39. CGC. Informe de Análisis de la Explotación Territorial Por Las Actividades Petroleras en Los Bloque 31 y 43 en Noviembre de 2018. Colectivo Geografía Crítica.: 1-10p. Available online: https://geografiacriticaecuador.org/wp-content/uploads/2019/05/ InformeInspeccion.pdf (accessed on 26 May 2021).

40. Franco, I.; Contin, M.; Bragato, G.; De Nobili, M. Microbiological resilience of soils contaminated with crude oil. Geoderma 2004, 121, 17-30. [CrossRef]

41. Aghalino, S.O.; Eyinla, B. Oil exploitation and marine pollution: Evidence from the Niger Delta, Nigeria. J. Hum. Ecol. 2009, 28, 177-182. [CrossRef]

42. Evans, A. Preservation or Exploitation? What to Do with Caribbean Ecosystem. J. Sustain. Dev. Stud. $2014,7$.

43. Bruederle, A.; Hodler, R. Effect of oil spills on infant mortality in Nigeria. Proc. Natl. Acad. Sci. USA 2019, 116, 5467-5471. [CrossRef] [PubMed]

44. Briggs, P.J.; Baron, P.R.; Fulleylove, R.J.; Wright, M.S. Development of heavy-oil reservoirs. J. Pet. Technol. 1988, 40, $206-214$. [CrossRef]

45. Boyer, C.; Kieschnick, J.; Suarez-Rivera, R.; Lewis, R.E.; Waters, G. Producing gas from its source. Oilfield Rev. $2006,18,36-49$.

46. Gregory, K.B.; Vidic, R.D.; Dzombak, D.A. Water management challenges associated with the production of shale gas by hydraulic fracturing. Elements 2011, 7, 181-186. [CrossRef]

47. Le Quang, M. The Yasuní-ITT initiative: Toward new imaginaries. Lat. Am. Perspect. 2016, 43, 187-199. [CrossRef]

48. Larrea, C. Conservación de la Biodiversidad y Explotación Petrolera en el Parque Nacional Yasuní; Universidad Andina Simón Bolivar: Quito, Ecuador, 2017.

49. Ramirez, M.I.; Arevalo, A.P.; Sotomayor, S.; Bailon-Moscoso, N. Contamination by oil crude extraction-Refinement and their effects on human health. Environ. Pollut. 2017, 231, 415-425. [CrossRef]

50. Finer, M.; Thieme, A.; Hettler, B. Explotación Petrolera se adentra más en el Parque Nacional Yasuní (Ecuador). Monit. Andean Amaz. Porject (MAAP). 2019, 114. Available online: https:// maaproject.org/2019/yasuni-itt/ (accessed on 26 May 2021).

51. Álvarez, D. Iniciativa Yasuní-ITT, un Instrumento Más de la Contradicción Estatal: Un Estudio de la Política de Conservación Desde la Agenda Pública. Master's Thesis, Facultad Latinoamericana de Ciencias Sociales Sede Ecuador, Quito, Ecuador, 2012.

52. López, A.V.; Espíndola, F.; Calles, J.; Ulloa, J. Atlas “Amazonía Ecuatoriana Bajo Presión”. EcoCiencia. Quito-Ecuador. 2013. Available online: https:/ / biblio.flacsoandes.edu.ec/libros / digital/56384.pdf (accessed on 13 June 2021).

53. Finer, M.; Vijay, V.; Ponce, F.; Jenkins, C.; Kahn, T. Ecuador's Yasuní Biosphere Reserve: A brief modern history and conservation challenges. Environ. Res. Lett. 2009, 4, 034005. [CrossRef]

54. Villacis, D. Corresponsabilidad de la comunidad internacional en la explotación del bloque 43 o ITT en el Parque Nacional Yasuní en Ecuador. Integr. Coop. Int. 2017, 24, 29-30.

55. Sovacool, B.K.; Scarpaci, J. Energy justice and the contested petroleum politics of stranded assets: Policy insights from the Yasuní-ITT Initiative in Ecuador. Energy Policy 2016, 95, 158-171. [CrossRef]

56. Albacete, C.; Espinosa, P.; Prado, W. Rapid Evaluation of the Gran Yasun'ı Napo; Parkswatch: Durham, NC, USA, 2004.

57. Narváez, I. Operación ITT: La última frontera extractiva en área de reserva natural y territorio Huaorani (primera edición). FLACSO-Biblioteca. Quito-Ecuador 1999, 75, 53.

58. Lombeyda, B. Propuesta Yasuní-ITT: Análisis Económico, Social y Ambiental; Facultad de Economía PUCE: Quito, Ecuador, 2010.

59. Alvaro, M. Petroamazonas gets green light on Ecuador's ITT oil block. Retrieved from The Wall Street Journal. 2014. Available online: http:/ / www.wsj.com/articles/SB (accessed on 2 May 2021).

60. Lessmann, J.; Fajardo, J.; Muñoz, J.; Bonaccorso, E. Large expansion of oil industry in the Ecuadorian Amazon: Biodiversity vulnerability and conservation alternatives. Ecol. Evol. 2016, 6, 4997-5012. [CrossRef] [PubMed] 
61. Moraes, M.; Paniagua-Zambrana, N.; Cámara-Leret, R.; Balslev, H.; Macia, M. Palmas útiles de Bolivia, Colombia, Ecuador y Perú. Cosecha Palmas en el Noroeste Suramérica Bases Científicas Para Su Manejo Conserv; Balslev, H., Macia, M., Navarrete, H., Eds.; Pontificia Universidad Católica del Ecuador: Quito, Ecuador, 2015; pp. 87-102.

62. Vogt, J. Ecological Conservation vs. Big Oil: The Case of Yasuní in Ecuador. DEcolonial Herit. Nat. Cult. Asymmetries Mem. 2018, 203,14 .

63. Cabrera, J.; Calva, L. Estudio del Límite Técnico en la Perforación de Pozos en el Campo Tambococha del Bloque 43. Tesis de Titulación. Universidad Central del Ecuador, Quito, Ecuador, 2019.

64. Guevara, J.; Pitman, N.; Cerón, C.; Rivas, G.; Beltrán, L.; Castro, R. Ministerio del Ambiente del Ecuador 2012. In Sistema de Clasificación de los Ecosistemas del Ecuador Continental; Ministerio del Ambiente del Ecuador: Quito, Ecuador, 2013; pp. 163-165, 175-177.

65. Cerón, C.; Palacios, W.; Guevara, J.; Aguirre, Z.; Encarnación, F.; Josse, C. Ministerio del Ambiente del Ecuador 2012. In Sistema de Clasificación de los Ecosistemas del Ecuador Continental; Ministerio del Ambiente del Ecuador: Quito, Ecuador, 2013 ; pp. 171-174.

66. SNI. Modelo de Unidades Geomorfológicas para la Representación Cartográficas de Ecosistemas del Ecuador Continental. 2014. Available online: https:/ /www.ambiente.gob.ec/wp-content/uploads/downloads/2012/09/Documento_Metodolog+\%C2\%A1 a2_05_2012_v2_1.pdf (accessed on 24 January 2021).

67. INEC. Censo 2010 de Población y Vivienda en el Ecuador: Fascículo Provincial Orellana. 2010. Available online: https: //www.ecuadorencifras.gob.ec/censo-de-poblacion-y-vivienda / (accessed on 22 January 2021).

68. Bass, M.S.; Finer, M.; Jenkins, C.N.; Kreft, H.; Cisneros-Heredia, D.F.; McCracken, S.F.; Pitman, N.C.A.; English, P.H.; Swing, K.; Villa, G.; et al. Global Conservation Significance of Ecuador's Yasuní National Park. PLoS ONE 2010, 5, e8767. [CrossRef] [PubMed]

69. Muñoz, D.; Rodríguez, M.; Romero, M. Análisis multitemporal de cambios de uso del suelo y coberturas, en la microcuenca las minas, corregimiento de La Laguna, municipio de Pasto, departamento de Nariño. Rev. Cienc. Agrícolas 2009, $26,11-24$.

70. Torres, B.; Andrade, L.; Torres, A.; Vasco, C.; Robles, M. Cambio de uso del suelo en paisajes agrícolas-forestales: Análisis espacial en cinco comunidades Kichwas de la Región Amazónica Ecuatoriana. Rev. Amaz. Cienc. Tecnol. 2018, 7, $105-118$.

71. Pidal, J.; Celi, J.; Yaguache, L. Efectos del cambio de cobertura del suelo en la geomorfología fluvial del río tena, Amazonía Ecuatoriana. In Proceedings of the Conferencia: III Encuentro Nacional de la Red Ecuatoriana de Ciencia RECIR Regional, Quito, Ecuador, 6 December 2017.

72. Jadán, O.; Torres, B.; Günter, S. Influencia del uso de la tierra sobre almacenamiento de carbono en sistemas productivos y bosque primario en Napo, Reserva de Biosfera Sumaco, Ecuador. Rev. Amaz. Cienc. Tecnol. 2012, 1, 173-184.

73. Lillesand, T.; Kiefer, R.; Chipman, J. Remote Sensing and Image Interpretation, 7th ed. 2015. Available online: https://www. wiley.com/en-ec/Remote+Sensing+and+Image+Interpretation\%2C+7th+Edition-p-9781118343289 (accessed on 6 April 2021).

74. Verburg, P.H.; Van De Steeg, J.; Veldkamp, A.; Willemen, L. From land cover change to land function dynamics: A major challenge to improve land characterization. J. Environ. Manag. 2009, 90, 1327-1335. [CrossRef] [PubMed]

75. Corina, M.; Martínez, A.; Viloria, J. Relación entre los cambios de cobertura vegetal y la ocurrencia de deslizamientos de tierra En la serranía del interior, Venezuela. Inerciencia 2016, 41, 15.

76. Venegas, J. Determinación y Análisis de Cambio del uso de Suelo en la Reserva Biológica de Limoncocha Entre los Años 1982 y 2000, Mediante la Aplicación de Herramientas y Técnicas Geoinformáticas. Master's Thesis, Universidad Internacional SEK, Quito, Ecuador, 2016.

77. FAO. Sistemas de Información Geográfica, Sensores Remotos y Mapeo Para el Desarrollo y la Gestión de la Acuicultura Marina [PDF File]. 2009. Available online: http:/ /www.fao.org/3/a0906s/a0906s.pdf (accessed on 3 February 2021).

78. Campbell, J.; Wynne, R. Introduction to Remote Sensing, 5th ed.; The Guilford Press: New York, NY, USA, 2011 ; pp. $170-175$.

79. Waserstrom, R.; Southgate, D. Deforestación, reforma agraria y desarrollo petrolero en Ecuador, 1964-1994. Nat. Resour. 2013, 4, 34-44.

80. Uyaguari, L. Análisis histórico de cambios en los patrones espaciales y temporales, en los paisajes protegidos del sector Dayuma, provincia de Orellana. Master's Thesis, Universidad Nacional de Loja, Loja, Ecuador, 2019.

81. Fernández, I.; Herrera, E. El Satélite Landsat: Análisis visual de imágenes obtenidas del sensor ETM+ Satélite Landsat. Universidad de Valladolid. Madrid España. P7. 2001. Available online: http://www.cartesia.org/data/apuntes/teledeteccion/landsatanalisis-visual.pdf (accessed on 13 February 2021).

82. Columba, M.; Quisilema, W.; Padilla, O.; Toulkeridis, T. Identificación de zonas de recurrencia de incendios forestales mediante análisis multitemporal y aplicación de índices espectrales, en el Distrito Metropolitano de Quito. Rev. Cienc. Segur. Def. 2016, 1, 7-13.

83. Hasmadi, M.; Pakhriazad, H.Z.; Shahrin, M.F. Evaluating supervised and unsupervised techniques for land cover mapping using remote sensing data. Geogr. Malays. J. Soc. Space 2009, 5, 1-10.

84. Meneses, C. El índice normalizado diferencial de la vegetación como indicador de la degradación. Unasylva 2011, 62, 40.

85. Vásquez, R. Uso de sistemas de información geográfica libres para la protección del medio ambiente. Univ. Soc. 2018, 10, 158-164.

86. Ojeda, N.; Soto, H. Clasificación y descripción fisiográfica de bosques de Araucaria araucana en el sur de Chile: Uso del satélite Landsat TM. UD y la Geomática 2018, 13, 106-113.

87. Souza, P.; Nascimento, W.; Santos, D.; Weber, E.; Silva, R.; Siqueira, J. A GEOBIA Approach for Multitemporal Land-Cover and Land-Use Change Analysis in a Tropical Watershed in the Southeastern Amazon. Remote Sens. 2018, 10, 1683. [CrossRef] 
88. Asghari, F.B.; Mohammadi, A.A.; Dehghani, M.H.; Yousefi, M. Data on assessment of groundwater quality with application of ArcGIS in Zanjan, Iran. Data Brief 2018, 18, 375-379. [CrossRef] [PubMed]

89. Damián, D. Análisis de la Dinámica de los Cambios de uso del Suelo Mediante Teledetección en una Microcuenca Alto Andina de Ecuador. Master's Thesis, Universidad de Valladolid, Madrid, España, 2017.

90. PDOTCA. Plan de Desarrollo y Ordenamiento Territorial del Cantón Aguarico: Diagnóstico por Componentes. 2015. Available online: http://app.sni.gob.ec/sni-link/sni/PORTAL_SNI/data_sigad_plus/sigadplusdiagnostico/PDYOT_AGUARICO_ ACTUALIZACI\%C3\%93N_FINAL_15-11-2014.pdf (accessed on 3 June 2021).

91. MAE. Línea Base de Deforestación del Ecuador Continental. 32p. 2012. Available online: http:/ / socioForestland.ambiente.gob.ec (accessed on 1 June 2021).

92. Puyravaud, J.P. Standardizing the calculation of the annual rate of deforestation. For. Ecol. Manag. 2003, 177, 593-596. [CrossRef]

93. Paula, P.A.; Zambrano, L.; Paula, P. Análisis Multitemporal de los cambios de la vegetación, en la Reserva de Producción de Fauna Chimborazo como consecuencia del cambio climático. Enfoque UTE 2018, 9, 125-137. [CrossRef]

94. Melo, J. Comparación de una Clasificación Supervisada para Coberturas Vegetales con PCI Geomatics y QGIS en el Municipio de Cundinamarca; Universidad Militar Nueva Granada: Bogotá, Colombia, 2017.

95. Sucoshañay, D.; Corral, V. Incremento de las actividades agropecuarias y disminución de la cobertura forestal en la cuenca del río Puyo en la Amazonia ecuatoriana, durante el periodo 2000-2013. Rev. GeoNordeste 2016, 2, 8-19.

96. Horton, A.; Constantine, J.; Hales, T.; Goossens, B.; Bruford, M.; Lazarus, E. Modification of river meandering by tropical deforestation. Geology 2017, 45, 511-514. [CrossRef]

97. Cadena, J. Estudio del Sistema Integral de la Cuenca del río Napo e incidencia de inundaciones a la ciudad de Francisco de Orellana, período: Junio Noviembre 2013. Master's Tesis, Universidad Laica “Eloy Alfaro” de Manabí, Manta, Ecuador, 2015; p. 75 .

98. Holland, M.; Koning, F.; Morales, M.; Naughton, L.; Robinson, B.; Suárez, L. Complex tenure and deforestation: Implications for conservation incentives in the Ecuadorian Amazon. World Dev. 2004, 55, 21-36. [CrossRef]

99. Trucíos, R.; Estrada, J.; Cerano, J.; Rivera, M. Interpretación del cambio en vegetación y uso de suelo. Tierra Latinoam. 2011, 29, 359-367. Available online: http:/ / www.scielo.org.mx/pdf/tl/v29n4/2395-8030-tl-29-04-00359.pdf (accessed on 21 June 2021).

100. Torres, B.; Bilsborrow, R.; Barbieri, R.; Torres, A. Cambios en las estrategias de ingresos económicos a nivel de hogares rurales en el norte de la Amazonía ecuatoriana. Rev. Amaz. Cienc. Tecnol. 2014, 3, 221-257.

101. Anzieta, E.M. Inscripción de Problema en la Agenda de Políticas Públicas: Análisis del caso de Moratoria Ishpingo-TiputiniTambococha (ITT). Master's Thesis, FLACSO Sede Ecuador, Quito, Ecuador, 2013.

102. Davidson, E.; Carioca, A.; Artaxo, P.; Balch, J.; Brown, F.; Cunha, M.; Coe, M.; Defries, R.; Keller, M.; Longo, M.; et al. The Amazon Basin in transition. Nature 2012, 481, 321-328. [CrossRef]

103. Ministerio del Ambiente [MAE]. Norma de Calidad Ambiental del Recurso Suelo y Criterios de Remediación Para Suelos Contaminados (Anexo 2, Libro VI de la Calidad Ambiental, del Texto Unificado de la Legislación Secundaria del Ministerio del Ambiente); Oficial, R., Ed.; LexisNexis: New Yoyk, NY, USA, 2015; Volume 387.

104. Petroamazonas, E.P. Estudio de Impacto y Plan de Manejo Ambiental del Proyecto Desarrollo y Producción de los Campos: Tiputini y Tambococha. Available online: https:/ / www.petroamazonas.gob.ec/ (accessed on 29 June 2021).

105. Petroamazonas, E.P. Actualización del Plan de Manejo Ambiental al Estudio de Impacto Ambiental para la Fase de Desarrollo y Producción de los Campos Tiputini y Tambococha. Available online: https:/ / www.petroamazonas.gob.ec/ (accessed on 29 June 2021).

106. Luna, L.A.L.; Lastra, O.R.E.; Buñay, A.P. La utopía de activación económica de la Amazonía ecuatoriana con los recursos de la Ley Amazónica. Estud. Desarro. Soc. Cuba. América Lat. 2021, 9, 138-147.

107. Calderón, E.M.P.; Jiménez, J.; Chávez, M.; Orellana, S.D.C. Legislación Ambiental, Regionalización y Presupuesto. Ley Orgánica de Planificación Integral de Circunscripción Territorial Especial Amazónica. Iustitia Soc. Rev. Arbitr. Cienc. Jurídicas Crim. 2020, 5 , 73-90.

108. MAGAP. Modelo de Gestión Para el Desarrollo de las 27 Comunidades de la Franja Diversidad y Vida del Cantón 816 Francisco de Orellana; Ministerio de Agricultura, Ganadería, Acuacultura y Pesca: Orellana, Ecuador, 2016; p. 39.

109. MAGAP. ATPA Proyecto Reconversión Agro Productiva Sostenible de la Amazonia; MAGAP: Quito, Ecuador, $2014 ;$ p. 815. 